\title{
On the Combinatory Nature of Knowledge Transfer Conditions: A Mixed Method Assessment
}

\author{
Emily Bacon ${ }^{1}$ (D) Michael D. Williams ${ }^{1} \cdot$ Gareth H. Davies $^{1}$
}

Accepted: 15 March 2021

(C) The Author(s) 2021

\begin{abstract}
Organisations are increasingly creating inter-organisational ecosystem partnerships to innovate openly. Despite effective knowledge management significantly supporting ecosystem infrastructures, empirical insights into the importance of and interdependencies between conditions for successful knowledge exchange across ecosystem contexts remain unexplored within existing literature. This study implements a mixed-method approach to ascertain which conditions are responsible for knowledge transfer success across innovation ecosystems. Interpretive Structural Modelling was employed to analyse questionnaires with key ecosystem stakeholders, in order to impose a hierarchical structure upon the conditions. The configurational nature of these conditions, and their combinations into solutions for success was ascertained through analysing semi-structured interviews using fuzzy-set Qualitative Comparative Analysis. Results reveal multiple, mutually exclusive pathways to knowledge transfer success, grouped into three solution types, increasing understanding of the interrelated nature of the knowledge transfer conditions. Limitations and implications for future research are provided.
\end{abstract}

Keywords Digital transformation $\cdot$ FsQCA $\cdot$ ISM $\cdot$ Ecosystem $\cdot$ Innovation $\cdot$ Knowledge transfer

\section{Introduction}

In an age of digital transformation, organisations are aspiring to provide innovative and intuitive solutions to address complex business challenges (Matzler et al., 2018). The ability to innovate formulates a key challenge within this era of digitisation: as such, new forms of collaboration are necessary to increase the likelihood of innovative success (Châlons \& Dufft, 2017). Involving knowledge movement between two or more organisations in a knowledge-intensive environment (Retzer et al., 2012) inter-organisational knowledge transfer acts as an enabler for digital transformation (Hossain \& Lassen, 2017; Nwankpa \& Roumani, 2016) creating a paradox around knowledge protection versus increased participation in knowledge sharing activities in order to generate digital innovations (Ilvonen et al., 2018). As such, sharing knowledge and data is crucial for innovation (Janssen et al., 2017); identifying new ways of combining innovations and

Emily Bacon

e.c.bacon@swansea.ac.uk

1 School of Management, Swansea University, Bay Campus, Swansea SA1 8EN, UK intensifying inter-organisational collaborations have become key characteristics for success (Ilvonen et al., 2018). It is necessary for organisations to collaborate with external partners to share information and consolidate existing knowledge to create new products that address market requirements (Chang et al., 2016). Co-creating with external partners through 'open innovation' (Chesbrough, 2003), organisations can share R\&D costs, minimise financial risks, and gain additional value (Gillespie et al., 2019).

Information systems research is experiencing a shift in focus, turning towards ecosystem evolution and the complex systems within which key technologies are now embedded (Majchrzak et al., 2016). Diverse ecosystem actors create and recombine knowledge in order to drive innovation (Sjödin, 2019), co-create value (Pera et al., 2016) and stimulate wider societal change (Appio et al., 2018). This leads to increased benefits for all actors involved in digital transformation, and information systems such as ecosystems play a critical role in this transformation (Pappas et al., 2018). Big data and business analytics are increasingly incorporated into contemporary business environments, necessitating an examination of how such technologies and their implementation are directed toward generating meaningful outcomes (Mikalef, Pappas, et al., 2020a). As such, the innovation potential embedded into large groups of individuals developing innovative 
technology-based solutions drives the emergence of a new paradigm of digital entrepreneurship (Elia et al., 2020). In ecosystem contexts, no individual actor operates in isolation, with all partners collaborating and interacting to co-create knowledge, whilst simultaneously evolving their interrelations to generate new technologies, companies, and value (Pappas et al., 2018). With digital technologies supporting an ecosystem (Jia et al., 2020), existing research has identified a requirement to investigate digital transformation in the context of ecosystems, particularly regarding the usage and accumulation of readily available knowledge (Radziwon \& Bogers, 2019). A recent literature review surrounding digital transformation within information systems literature calls for further understanding on how communication and coordination occur in ecosystem contexts (Vial, 2019). Most studies adopt an intra-organisational perspective; however, given that digital transformation substantially influences interorganisational ecosystem partnerships where value is cocreated between multiple organisations, inter-organisational perspectives require further research (Riasanow et al., 2020). Radziwon and Bogers (2019) state that further comparative studies are necessary to examine multiple ecosystems, with mixed strategic profiles and high versus low tech companies; they further identify a need to examine knowledge exchange and management within these ecosystem contexts. Given the relationship between knowledge transfer and digital transformation (Hossain \& Lassen, 2017) existing research agendas further emphasise a requirement for additional research that establishes the mechanisms for knowledge exchange across innovation ecosystems (Suominen et al., 2019) as well as the interdependencies between the mechanisms (Milagres \& Burcharth, 2019) as observing the configurational aspects of ecosystems requires an information systems perspective (Vassilakopoulou \& Hustad, 2021). In addressing these calls for research, this investigation identifies configurations of conditions for knowledge transfer success as facilitators for innovative developments across innovation ecosystems.

While previous scholars (Bacon et al., 2019a) have analysed knowledge transfer conditions for open innovation, their research cannot be applied to the ecosystem as a whole, thus failing to provide insights into the configurational nature of knowledge transfer success. In remedying this absence, this investigation poses two key research questions: firstly, within ecosystem contexts, do certain conditions carry greater prominence for knowledge transfer success? Secondly, what are the interrelations between knowledge transfer conditions in ecosystem contexts? To address this question, two methods of analysis will be applied. Innovation-related outcomes have been analysed by other scholars using fuzzy-set Qualitative Comparative Analysis (fsQCA; Kraus et al., 2018; Soto Setzke et al., 2021) and other novel techniques such as Interpretive Structural Modelling (ISM; Dwivedi et al., 2017). However, their amalgamation within a single study is seldom observed in management literature. As both ISM (Singh et al., 2003) and fsQCA (Ragin, 2008) are grounded upon the principles of complexity, their synthesis within this research provides a more comprehensive deconstruction of the complex outcome of success (Woodside, 2013). To avoid an overreliance and overconfidence upon a single research method, researchers should employ multiple methods in a single study (Brewer \& Hunter, 2006). The application of a mixedmethod approach in this paper originates from a lack of theorisation surrounding the configurational nature of knowledge transfer conditions in the context of innovation ecosystems. Mixed-method studies are highly suitable for addressing fragmented, inconclusive, and ambiguous findings (Venkatesh et al., 2013). Hence, this investigation combines two analytical tools - fsQCA and ISM - to conduct a more holistic analysis into the conditions responsible for knowledge transfer success across open innovation ecosystems.

The remainder of this paper is structured as follows. Section 2 reviews existing literature surrounding knowledge transfer within innovation ecosystems. Section 3 summarises the conceptual framework underlying this study. Section 4 presents the first study conducted in this investigation, including methods of data collection and analysis, and research results: in a similar manner, Section 5 presents the second study. Section 6 discusses the main findings of both studies. Closing observations, alongside theoretical and practical implications and limitations of this study, are provided in Section 7.

\section{Existing Literature}

Digitisation has transformed the nature of openness in innovation contexts in terms of who can participate, what and how they can contribute, and to what ends (Nambisan et al., 2019). Open innovation (Chesbrough, 2003) comprises an organisational openness towards external knowledge sources, with firms transferring such knowledge across their organisational boundaries. Involving the movement of knowledge between actors (Van Wijk et al., 2008), interorganisational knowledge transfer facilitates the acquisition of new ideas (Chiang \& Hung, 2010) and is critical for the innovation process (Charband \& Navimipour, 2016).

The increasing complexity of knowledge demands multiple innovation partnerships in order to increase the likelihood that relevant innovation requirements will be addressed (Bogers, 2011). In the context of open innovation, networks and ecosystems enable organisations to access external knowledge (Chesbrough et al., 2006). Ritala and Almpanopoulou (2017) define innovation ecosystems as "profit-driven systems of innovation around focal companies, technologies and platforms... systems that focus on innovation activities (goal/purpose), involve the logic of actor interdependence within a particular context (spatial dimension) 
and address the inherent co-evolution of actors (temporal dimension)" (p.7). Innovation ecosystems enable regional collaboration, both nationally and internationally, through allowing organisations to combine skills and share resources to drive benefits for all involved partners (Ferreira \& Teixeira, 2019) expediting open innovation through enabling firms to access a plethora of knowledge transfer partners, fostering connectivity and knowledge co-creation (CanoKollmann et al., 2016). Previous literature investigates this inter-organisational knowledge transfer process for open innovation within network- (Xie et al., 2016) ecosystem- (Miller et al., 2016; Secundo et al., 2019; Shaikh \& Levina, 2019; Wulf \& Butel, 2017) and community-level analyses (Pirkkalainen et al., 2018; Randhawa et al., 2017). What is absent from these existing research articles is a directed focus towards identifying how conditions for knowledge transfer success are managed and maintained within open innovation ecosystems (Bacon et al., 2019a). Previous studies have explored factors for collaboration in social media ecosystems (Dwivedi et al., 2021) but not open innovation ecosystems specifically. Ferreira and Teixeira's (2019) special issue on open innovation and business ecosystems includes a number of significant papers exploring distinct concepts of open innovation and knowledge, including knowledge leaks in open innovation ecosystems (Giusti et al., 2018), obstacles to cooperation within university research centres (Franco \& Pinho, 2019), and the roles of open innovation partners in improving economic and innovation performance (Rauter et al., 2018). The objective of this special issue by Ferreira and Teixeira (2019) is to illuminate the role of open innovation and knowledge on ecosystem development: to expand upon these insights and further contribute to this discussion, this paper focuses on knowledge transfer success within open innovation ecosystems. Reviews of open innovation literature (Bogers et al., 2017; Hossain et al., 2016; Kovacs et al., 2015) further emphasise that constituents of knowledge transfer success in ecosystem contexts remain unexplored. Moreover, existing research commonly examines ecosystems at macro-levels of analysis (Adner \& Kapoor, 2010; Engler \& Kusiak, 2011; Rohrbeck et al., 2009). Information exchange supports the ecosystem infrastructure (Kannisto et al., 2020). With knowledge and innovation occurring at the micro-level, and given the embeddedness of the individual within their ecosystem (Gonçalves et al., 2019), the significant role of individuals in supporting the ecosystem infrastructure requires further theoretical attention (Milagres \& Burcharth, 2019).

Despite a number of comprehensive reviews that examine factors affecting knowledge transfer across ecosystem partnerships (Bacon et al., 2019a, 2019b; Miller et al., 2016; Secundo et al., 2019; Shaikh \& Levina, 2019; Wulf \& Butel, 2017), the interrelations between the key conditions regarding innovation ecosystems as whole are yet to be confirmed by existing studies. Hierarchical associations between such conditions remain largely unaddressed in the context of innovation ecosystems (Bacon et al., 2019a, 2019b). Recent research agendas (Milagres \& Burcharth, 2019) identify a requirement to analyse condition interdependencies, in order to encapsulate a more holistic depiction of success: the high failure rate of many innovation partnerships (Lauritzen \& Karafyllia, 2019) arguably derives from the absence of a comprehensive understanding of how success is achieved in these contexts (Milagres \& Burcharth, 2019). It is hence recommended that a deconstruction of success into its related components, and identifying how these conditions interact, will contribute towards ensuring knowledge transfer is able to support the ecosystem as a whole (Bacon et al., 2019b).

\section{Conceptual Framework}

\subsection{Selecting the Conditions}

Existing research aims to increase understanding of how knowledge transfer success is achieved (Al-Salti \& Hackney, 2011; Cummings \& Teng, 2003; Hasty et al., 2006) with studies commonly exploring the influence of single antecedents of knowledge transfer (Abrams et al., 2003; Ambos \& Ambos, 2009; Minbaeva \& Michailova, 2004; Simonin, 1999). However, success is an inherently complex phenomenon that is unlikely to derive from a single factor (Woodside, 2013). Moreover, existing research typically utilises variance-based techniques (Becerra et al., 2008; Chen, 2004; Lee, 2001; Santoro \& Bierly, 2006) that are unable to illuminate how success may be achieved in many different ways (Woodside, 2013). As such, this investigation aims to deconstruct the configurational nature of the knowledge transfer conditions, identifying how system elements can be combined in multiple and complex ways (Ortiz de Guinea \& Raymond, 2020).

Conditions were only included in this study if found to possess theoretical interrelations with extant literature, as observed in previous knowledge transfer research (Bacon et al., 2019a, 2019b; Milagres \& Burcharth, 2019; Van Wijk et al., 2008). Table 1 displays the included conditions.

Whilst interrelated, each condition purports distinct characteristics. Hence, the conditions are organised into three categories: knowledge-, relationship-, and firm-related (Bacon et al., 2019a).

\subsection{Knowledge Characteristics}

The knowledge exchanged between ecosystem partners arguably requires specific characteristics to ensure its successful transfer. Firstly, the nature of the knowledge itself affects the process. Knowledge can commonly be typified as either tacit or explicit. Tacit knowledge is more difficult to articulate, 
Table 1 Relationships between knowledge transfer conditions

\begin{tabular}{|c|c|}
\hline Condition & Citation \\
\hline Knowledge Type and Trust & Panteli and Sockalingam (2005); Roberts (2000) \\
\hline Knowledge Type and Tie Strength & Van Wijk et al. (2008) \\
\hline Knowledge Type and Cultural Similarity & Ismail (2012) \\
\hline Knowledge Type and Causal Ambiguity & Reed and DeFillippi (1990); Simonin (1999) \\
\hline Knowledge Type and Learning Intent & Cummings and Teng (2003); Pérez-Nordtvedt et al. (2008) \\
\hline Knowledge Type and Absorptive Capacity & Spulber (2012) \\
\hline Knowledge Type and Understanding & Al-Salti and Hackney (2011); Pak and Park (2004); Simonin (1999) \\
\hline Understanding and Trust & Abrams et al. (2003); Dodgson (1993); Nielsen (2005) \\
\hline Understanding and Tie Strength & Van Wijk et al. (2008) \\
\hline Understanding and Cultural Similarity & $\begin{array}{l}\text { Al-Salti and Hackney (2011); Evangelista (2007); } \\
\text { Szulanski et al. (2004); Van Wijk et al. (2008) }\end{array}$ \\
\hline Understanding and Causal Ambiguity & Van Wijk et al. (2008) \\
\hline Understanding and Learning Intent & Al-Salti and Hackney (2011) \\
\hline Understanding and Absorptive Capacity & Lawson and Potter (2012) \\
\hline Causal Ambiguity and Cultural Similarity & Williams (2007) \\
\hline Causal Ambiguity and Trust & Shamsudin et al. (2016). \\
\hline Causal Ambiguity and Tie Strength & Van Wijk et al. (2008) \\
\hline Causal Ambiguity and Learning Intent & Lawson and Potter (2012) \\
\hline Causal Ambiguity and Absorptive Capacity & King and Zeithaml (2001) \\
\hline Trust and Tie Strength & Inkpen and Tsang (2005); Narteh (2008); Wulf and Butel (2017) \\
\hline Trust and Cultural Similarity & Szulanski et al. (2004); Zhang and Zhou (2013) \\
\hline Trust and Learning Intent & Maurer et al. (2011); Szulanski et al. (2004) \\
\hline Trust and Absorptive Capacity & Lane et al. (2001); Martinkenaite (2011) \\
\hline Tie Strength and Absorptive Capacity & Gao et al. (2008) \\
\hline Tie Strength and Learning Intent & Xie et al. (2015) \\
\hline Cultural Similarity and Absorptive Capacity & Junni and Sarala (2013) \\
\hline Cultural Similarity and Tie Strength & Lizardo (2006) \\
\hline Cultural Similarity and Learning Intent & Zahra et al. (2018) \\
\hline Absorptive Capacity and Learning Intent & Lawson and Potter (2012) \\
\hline
\end{tabular}

encompassing the more personalised and experiential side of knowledge: alternatively, explicit knowledge is transmittable in formal, systematic language, and is argued to be easier to transfer (Nonaka et al., 1996). It is hence assumed that explicit knowledge directly improves the transfer process, whilst tacit knowledge hinders it (Al-Salti \& Hackney, 2011). The articulability of such knowledge can arguably be measured through the degree of understanding possessed by the recipient organisation (Bacon et al., 2019a). Because tacit knowledge is embedded within individuals' cognitive processes, it is more difficult to explain precisely (Kang et al., 2010): tacit knowledge retains complex structures that are difficult to understand and hence cannot be comprehended or communicated fully (Koskinen, 2000). Tacit knowledge can be understood in multiple ways, emphasising is a requirement to determine a common understanding of the construct (Harlow, 2008). Knowledge transfer success ultimately derives from understanding the knowledge received (Cummings \& Teng, 2003).

In relation to knowledge type, causal ambiguity is often cited as affecting the transfer process. According to Lippman and Rumelt (1982), causal ambiguity reflects a basic ambiguity surrounding the causal connections between actions and results: in other words, the origins of the knowledge itself are unclear. This presents difficulties for the firm, both organisationally and at an individual level (Reed \& DeFillippi, 1990) when attempting to replicate and transfer such knowledge: as such, low causal ambiguity prevents this barrier to imitation. In sum, the knowledge characteristics identified within extant literature as affecting the transfer process are knowledge type \& understanding, and causal ambiguity. This paper aligns with extant knowledge transfer literature that defines knowledge type and causal ambiguity as separate constructs (Easterby-Smith et al., 2008; 
Gopalakrishnan \& Bierly, 2001; Michailova \& Mustaffa, 2012); whilst some literature includes causal ambiguity and knowledge type under a single variable name such as knowledge context (Cummings \& Teng, 2003) this paper analyses them separately, but under the umbrella term of knowledgecharacteristics.

\subsection{Relationship Characteristics}

Knowledge transfer literature frequently designates trust between partners as increasing the likelihood of success. Trust refers to a willingness of a partner to be 'vulnerable' and take risks (Mayer et al., 1995) as well as being a reliable source of knowledge through fulfilling partner expectations (Inkpen, 1998). Within a trustworthy partnership, partners are more likely to absorb and transfer useful knowledge, as well as making the overall process less costly (Levin \& Cross, 2004). Relatedly, the strength of the personal relationship between these partners can further affect the transfer process (Cummings \& Teng, 2003; Van Wijk et al., 2008). These strong relationships involve high levels of emotion and frequent interactions which increase opportunities for knowledge exchange (Rejeb-Khachlouf et al., 2011). Such highly personalised relationships encourage organisations to spend more time on the transfer process, ensuring that partners understand the information received (Van Wijk et al., 2008). Finally, similarities between organisational cultures arguably facilitate transfer success (Evangelista, 2007; He et al., 2011). Cultural similarities encompass a shared vision, encouraging similar perceptions between organisations regarding their expectations of the partnership (Fang et al., 2013). This facilitates mutual understanding between organisations, providing a bonding mechanism that expedites knowledge integration (Van Wijk et al., 2008). It is therefore favourable in terms of innovation to foster trustworthy, strong, and culturally compatible relationships between ecosystem members to encourage successful knowledge exchange.

\subsection{Organisational Characteristics}

Characteristics of ecosystem partners themselves further impact upon the transfer process. The learning intent of the recipient organisation comprises a further facilitator of knowledge transfer. Learning intent involves an organisational motivation and commitment to learn from others, operating as a driving force for individuals to pursue a partnership (Evangelista, 2007) and encouraging knowledge articulation and codification (Al-Salti \& Hackney, 2011). Relatedly, absorptive capacity, referring to the ability of an organisation to recognise knowledge value, diffuse it internally, and apply it to commercial ends, comprises a further organisational characteristic that improves the success rate of knowledge transfer (Van Wijk et al., 2008). Individuals need to hence ensure that the knowledge received is fully integrated and at a position to be efficiently transferred (Al-Salti \& Hackney, 2011). Hence, learning intent and absorptive capacity formulate organisational characteristics which expedite the transfer process.

\subsection{Conceptual Model}

The seven conditions underlying the conceptual model originate from a larger body of research that identifies further additional factors as facilitators of knowledge transfer. This emphasises that it is unlikely that a single condition will be responsible for success, reflecting the notion of conjunctural causation, whereby no single condition causes the presence or absence of an outcome ( $\mathrm{Wu}, \mathrm{Yeh}$, Huan and Woodside, 2014). In line with complexity theory, this investigation supports such a notion, purporting that multiple conditions are likely to produce an outcome of knowledge transfer success. Complexity theory further endorses equifinality, where different causal paths can lead to the same outcome (Fiss, 2011). The multitude of conditions cited within existing research presents uncertainties as to how these conditions combine and interact to instigate success. As such, two or more configurations of conditions can be equally effective in explaining knowledge transfer success (Fiss, 2007). Thus, it is argued that combinations of conditions across knowledge-, firmand relationship-related characteristics will contribute to knowledge transfer success. This study views success as "active exchange of knowledge between organizations, involving measurable and effective knowledge absorption, application and satisfaction by the recipient organization" (Bacon et al., 2019a, p.380). Figure 1 displays all logically possible combinations of the characteristics, comparable to the diagram generated by Ortiz de Guinea and Raymond (2020).

\section{Study 1}

\subsection{Procedure and Subjects}

Existing studies explore ecosystem partnerships from the perspective of key stakeholders, utilising both interviews (Franco \& Pinho, 2019; Miller et al., 2016; Randhawa et al., 2017; Shaikh \& Levina, 2019; Wulf \& Butel, 2017) and questionnaires (Pirkkalainen et al., 2018; Rauter et al., 2018; Xie et al., 2016) to ascertain individual perceptions regarding their partnerships. Given existing evidence citing role of the individual in facilitating the presence of knowledge transfer conditions (Al-Salti \& Hackney, 2011; Kang et al., 2010; Reed \& DeFillippi, 1990; Van Wijk et al., 2008) this study mimics existing research within this domain through utilising individual employees to formulate an understanding of their perceptions of their ecosystem partnerships, hence selecting these 


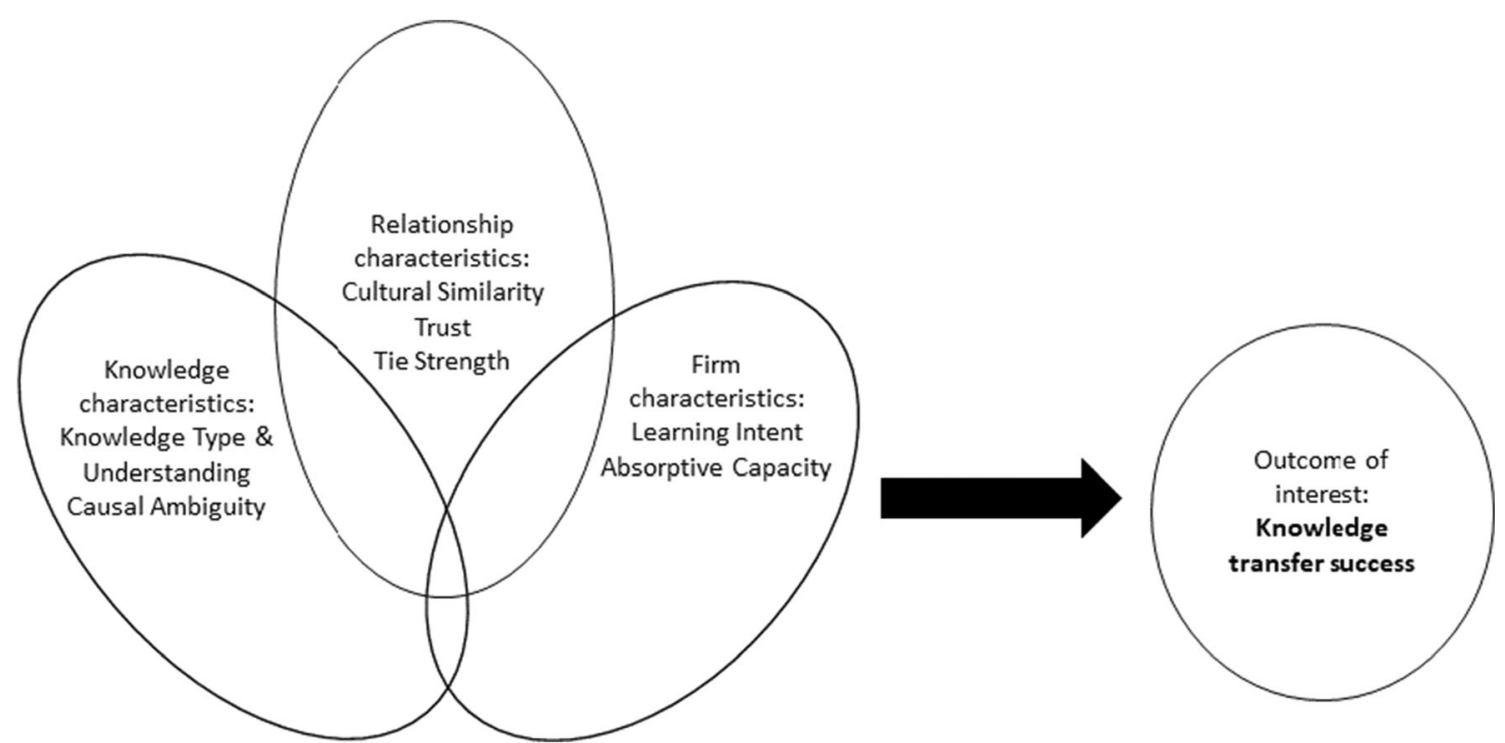

Fig. 1 Conceptual Model

individuals as the unit of analysis. These individual perceptions were deemed representative of the ecosystem partnership. While conditions such as cultural similarity may not occur at the micro-level, this paper uses individual perceptions to obtain insights into knowledge transfer success across ecosystem partnerships: thus, in line with existing knowledge transfer literature (Cummings \& Teng, 2003; Evangelista, 2007; Simonin, 1999) this study utilises individual-level analyses to obtain perceptions of knowledge, relationship, and organisational characteristics.

For both phases of analysis, participants were recruited via snowball sampling. Participants were asked to provide contact details for potentially suitable participants, who were subsequently contacted and invited to participate. For the first phase of analysis, employees from a multinational organisation were invited to complete an online questionnaire. The multinational adopted a centralised position as an orchestrator of its ecosystems. Participants were deemed experts in ecosystem engagement due to their wealth of experience, and included alliance managers, partner management coordinators, and strategic partnership managers. The online questionnaire required participants to assess the relationships between the knowledge transfer conditions. The opening section of the questionnaire provided a description of the conditions: this description was included at the start of every page to facilitate participant understanding. As per standard ISM protocol (see Azevedo et al., 2013), each individual question asked participants to assess the pairwise relationship between the conditions, selecting one option from a list of four options: (1) Condition A influenced Condition B; (2) Condition B influenced Condition $\mathrm{A}$; (3) the conditions influence each other; or (4) no relationship exists between the conditions. This resulted in a total of 34 questions assessing the pairwise relationships between each of the conditions in their entirety. Eleven participants responded to the questionnaire: their individual responses were collected, and consensus was obtained through observing the most common response within the group.

\subsection{Interpretive Structural Modelling}

The first phase of data collection utilised questionnaires to establish the relationships between the knowledge transfer conditions and were analysed using ISM. ISM was utilised to confirm whether the relationships were viewed as interrelated by key ecosystem stakeholders, and to ascertain whether specific conditions displayed greater prominence. An interactive and interpretive method, ISM utilises a consensus gained from group judgements to ascertain how certain variables are related (Mandal \& Deshmukh, 1994). Individuals are asked to establish the relationships between variables: these individuals are usually experts within the given area of investigation (Azevedo et al., 2013). As ISM relies on individuals assessing whether each individual factor relates to every other factor under investigation, it can be utilised to detect the relationships been variables. Whilst ISM can be conducted as a group learning process, it can also be utilised individually (Ravi \& Shankar, 2005): the individual opinions of experts are frequently sought through questionnaires (Alawamleh \& Popplewell, 2011; Govindan et al., 2015; Kumar et al., 2013; Pfohl et al., 2011; Sahney et al., 2006; Samantra et al., 2016; Soti et al., 2011; Tripathy et al., 2013). Individual responses to the questionnaire were summed and the most common response utilised to represent consensus, as observed within existing ISM literature (Alawamleh \& Popplewell, 2011; Samantra et al., 2016; Tripathy et al., 2013).

ISM attempts to alleviate complexity through yielding both a graphical and modular representation of the interrelated 
elements comprising a wider, more complex system (Nishat Faisal et al., 2006; Ravi \& Shankar, 2005; Singh et al., 2003). Such a model enables the identification and ordering of the complex relations between the elements, allowing an analysis of the influence of each element (Sahney et al., 2006). It can thus be used to prioritise and improve understanding of the key relationships between variables (Tripathy et al., 2013). The identified order of these interrelated elements thus facilitates an understanding of their varying influences (Talib et al., 2011).

\subsubsection{Stages in ISM}

The application of ISM within any given research context is typically comprised of a series of stages (see Alawamleh \& Popplewell, 2011; Singh and Kant, 2008; Talib et al., 2011). These stages are explicated within this section to inform understanding of the exact features of the analytical technique, as outlined by Pfohl et al. (2011).

The starting point for the ISM analysis is the identification of the specific variables relevant to the problem under investigation. This can be achieved through primary or secondary research. Next, the type of relationship between the variables must be determined. Relationships can adopt various typologies, including temporal, comparative, influence, or neutral (Warfield, 1994).

Participants must then use their experience and knowledge to decide upon the pairwise relationships between the elements, selecting one of four options to represent the direction of the relationship:

- $\quad \mathrm{V}=\mathrm{i}$ influences $\mathrm{j}$

- $A=j$ influences $\mathrm{i}$

- $\mathrm{X}=$ variables $\mathrm{i}$ and $\mathrm{j}$ influence each other

- $\mathrm{O}=$ no relationship

This is used to develop a Structural Self-Interaction Matrix. These pairwise relations are then converted into numbers to form an Initial Reachability Matrix, utilising the following logic:

- If the $(i, j)$ entry is $V$, the $(i, j)$ entry in the reachability matrix becomes 1 , and the $(\mathrm{j}, \mathrm{i})$ entry becomes 0 .

- If the $(i, j)$ entry is $A$, the $(i, j)$ entry in the reachability matrix becomes 0 and the (j,i) entry becomes 1 .

- If the (i,j) entry is $X$, the $(i, j)$ and $(j, i)$ entries in the reachability matrix both become 1 .

- If the (i,j) entry is $\mathrm{O}$, the $(\mathrm{i}, \mathrm{j})$ and $(\mathrm{j}, \mathrm{i})$ entries in the reachability matrix both become 0 .

The reachability matrix is then further refined based upon the assumption of Transitivity, which states that if $\mathrm{A}$ is related to $\mathrm{B}$ and $\mathrm{B}$ is related to $\mathrm{C}$, then $\mathrm{A}$ and $\mathrm{C}$ are related. This principle is used to alter the entries for variables which are indirectly related. The reachability matrix also demonstrates the driving and dependence power of each condition. Driving power refers to the total number of conditions it affects, i.e. the sum of the rows. The dependence power refers to the total number of conditions by which it is affected - i.e. the sum of the columns. Both the driving and dependence power are used to classify the conditions into autonomous, dependent, linkage, and independent conditions. Next, reachability and antecedent sets are derived for each factor, to facilitate the construction of a digraph from the reachability matrix. The reachability set consists of the factor itself and the other factor it may impact, whereas the antecedent set consists of the factor itself and the other factor that may impact it (Dwivedi et al., 2017). The intersection of both sets, i.e. the common elements for both sets, are identified. Factors within these intersections occupy the top-level within the ISM hierarchy. Top-level elements do not relate to any other element above their level, and they are removed from the other elements once they are identified. This iteration process is conducted until the levels for all elements are identified. An initial digraph with transitivity links is hence obtained from the conical form of the reachability matrix. The conical matrix is generated through rearranging all the elements according to their level, whereby all the elements with the same level are pooled together. Transitivity links are removed for the final digraph. Element nodes are replaced with statements, which converts the digraph into an Interpretive Structural Model. The model is checked for conceptual consistency.

ISM has thus been selected as the first method of data analysis within this study. A number of studies have used the survey method to obtain consensus from experts (Govindan et al., 2015; Kumar et al., 2013; Sahney et al., 2006; Soti et al., 2011). Expert opinion within the ISM approach can be sought from any number of individuals: existing questionnaire-based studies (Azevedo et al., 2013; Dubey \& Ali, 2014; Govindan et al., 2015) have used between five and eleven participants. The ability of ISM to provide concrete evidence of the relationships between conditions will be a viable addition to this research in terms of providing confirmation of their importance.

\subsection{ISM Results}

11 experts were consulted on their opinions of the relationships between the conditions. A contextual relationship of 'influences' was selected due to the fact that the conditions were expected to exhibit an influencing relationship, as previously found in existing studies (see Table 1). Table 2 displays the SSIM matrix based on the VAXO denotations.

The Structural Self-Interaction Matrix was converted into an Initial Reachability Matrix (Table 3), by replacing the VAXO entries with $1 \mathrm{~s}$ and $0 \mathrm{~s}$. 
Entries coded as 0 within the Initial Reachability Matrix were reviewed based upon the principle of transitivity. If two conditions were identified as having no relationship, their relationship was re-analysed: if Condition $\mathrm{A}$ was related to Condition B, and Condition B was related to Condition C, then Conditions $\mathrm{A}$ and $\mathrm{C}$ were characterised as related. These transitive links resulted in unrelated conditions being re-coded as related, albeit indirectly, indicated by a 1 . This principle was used to obtain the Final Reachability Matrix (Table 4). The driving and dependence power of all conditions are also displayed in Table 4.

The final reachability matrix was used to derive the reachability and antecedent sets for each condition. This resulted in the level partitions for the conditions (Table 5).

As the reachability and intersection sets are the same for all conditions, there is only one level present in the final digraph. The conical form of the reachability matrix has been excluded: due to all conditions occupying the same level, the conical form is the same as the final reachability matrix. Figure 2 displays the final digraph obtained from the ISM analysis. The arrows display the bi-directional nature of the relationships.

\section{Study 2}

\subsection{Procedure and Subjects}

The second phase of analysis expanded the sample to include participants from the ecosystems of the multinational orchestrator. Ecosystem partners were invited to offer their perceptions of the seven aforementioned conditions through a semistructured interview, an appropriate methodological technique for capturing relevant data for fsQCA (Iannacci et al., 2020; Mikalef, Sharma, et al., 2020b). A total of 30 participants were interviewed and represented the three main organisational typologies typically observed within ecosystem infrastructures: multinational, SME, and university (Carayannis \& Campbell,
2009). The sample included 19 males and 11 females, hence demonstrating a slight bias toward the male gender; as ecosystem stakeholder perspectives were sought for this study, it was determined that the relative imbalance between male and female participants would not affect study results. Participants were located across a range of industries, including technology (10), finance (2), telecommunications (2), transport (1), services (3), software (2) and education (10); all were involved in ecosystem partnerships that centred around the development of an innovation, albeit at different stages of the process. Various organisational positions were held by participants, including directors (6), department heads (11), managers (9), chief technology officers (2), and professors (2).

Ten interviews were conducted for each category in order to increase comparability between the organisation types, resulting in a total of 30 participants. The interviews asked participants to rate the extent of their agreement on a sevenpoint semantic differential scale: opposing terminology (e.g. untrustworthy/trustworthy) was positioned at either end of the scale to correspond to the presence or absence of the knowledge transfer conditions. The definitions for each condition were adapted from key studies examining the construct in the context of knowledge transfer wherever possible (Table 6). Single-item semantic differential scales can be utilised for fsQCA to assess the presence and absence of conditions (Seate et al., 2015): however, critics have argued that such scales can be questionable in terms of reliability and validity (Al-Hindawe, 1996). Hence, Al-Hindawe (1996) argues that semantic differential scales should be supplemented with unstructured questions to further elucidate the results of the scale ratings. Participants were hence encouraged to expand upon their scale ratings through additional unstructured questions. This enabled more detailed insights into each partnership, resulting in greater encapsulation to transform the interviews from scale and qualitative data into 'cases' for fsQCA. Table 6 displays the scales and unstructured questions utilised in the interviews.

Table 2 Structural Self-Interaction Matrix

\begin{tabular}{|c|c|c|c|c|c|c|c|c|}
\hline & $\begin{array}{l}\text { Type of } \\
\text { Knowledge }\end{array}$ & Understanding & $\begin{array}{l}\text { Causal } \\
\text { Ambiguity }\end{array}$ & Trust & $\begin{array}{l}\text { Tie } \\
\text { Strength }\end{array}$ & $\begin{array}{l}\text { Cultural } \\
\text { Similarity }\end{array}$ & $\begin{array}{l}\text { Learning } \\
\text { Intent }\end{array}$ & $\begin{array}{l}\text { Absorptive } \\
\text { Capacity }\end{array}$ \\
\hline \multicolumn{9}{|l|}{$\begin{array}{l}\text { Type of } \\
\text { Knowledge }\end{array}$} \\
\hline Understanding & $X$ & & & & & & & \\
\hline Causal Ambiguity & $\mathrm{V}$ & $\mathrm{X}$ & & & & & & \\
\hline Trust & $\mathrm{V}$ & $\mathrm{X}$ & $\mathrm{X}$ & & & & & \\
\hline Tie Strength & $\mathrm{X}$ & $\mathrm{O}$ & $\mathrm{X}$ & $\mathrm{X}$ & & & & \\
\hline Cultural Similarity & $\mathrm{X}$ & $\mathrm{X}$ & $\mathrm{X}$ & V & V & & & \\
\hline Learning Intent & $\mathrm{X}$ & $\mathrm{X}$ & $\mathrm{X}$ & $\mathrm{O}$ & $\mathrm{A}$ & $\mathrm{X}$ & & \\
\hline $\begin{array}{l}\text { Absorptive } \\
\text { Capacity }\end{array}$ & $\mathrm{X}$ & $\mathrm{X}$ & $\mathrm{X}$ & $\mathrm{X}$ & $\mathrm{X}$ & $\mathrm{X}$ & $\mathrm{X}$ & \\
\hline
\end{tabular}


Table 3 Initial Reachability Matrix

\begin{tabular}{|c|c|c|c|c|c|c|c|c|}
\hline & $\begin{array}{l}\text { Type of } \\
\text { Knowledge }\end{array}$ & Understanding & $\begin{array}{l}\text { Causal } \\
\text { Ambiguity }\end{array}$ & Trust & $\begin{array}{l}\text { Tie } \\
\text { Strength }\end{array}$ & $\begin{array}{l}\text { Cultural } \\
\text { Similarity }\end{array}$ & $\begin{array}{l}\text { Learning } \\
\text { Intent }\end{array}$ & $\begin{array}{l}\text { Absorptive } \\
\text { Capacity }\end{array}$ \\
\hline $\begin{array}{l}\text { Type of } \\
\text { Knowledge }\end{array}$ & 1 & 1 & 0 & 0 & 1 & 1 & 1 & 1 \\
\hline Understanding & 1 & 1 & 1 & 1 & 0 & 1 & 1 & 1 \\
\hline Causal Ambiguity & 1 & 1 & 1 & 1 & 1 & 1 & 1 & 1 \\
\hline Trust & 1 & 1 & 1 & 1 & 1 & 0 & 0 & 1 \\
\hline Tie Strength & 1 & 0 & 1 & 1 & 1 & 0 & 1 & 1 \\
\hline Cultural Similarity & 1 & 1 & 1 & 1 & 1 & 1 & 1 & 1 \\
\hline Learning Intent & 1 & 1 & 1 & 0 & 0 & 1 & 1 & 1 \\
\hline $\begin{array}{r}\text { Absorptive } \\
\text { Capacity }\end{array}$ & 1 & 1 & 1 & 1 & 1 & 1 & 1 & 1 \\
\hline
\end{tabular}

This study views success as "active exchange of knowledge between organizations, involving measurable and effective knowledge absorption, application and satisfaction by the recipient organization" (Bacon et al., 2019a, p.380). To identify membership within the outcome, this definition was embedded within the interviews as five separate semanticdifferential scales, corresponding to the five separate components of this definition (Table 7).

\subsection{FsQCA}

FsQCA aims to establish which specific causal conditions interact to produce a given outcome (Ragin, 2008). According to Ragin (2008), fsQCA can be utilised to examine cases sharing a specific causal condition, or combination of causal conditions, and assess whether these cases exhibit the same outcome. It aims to address two seemingly paradoxical yet essential objectives: to afford greater insights into case studies, whilst capturing their complexity (Rihoux \& Lobe, 2009). Applications of fsQCA in information systems research have increased in recent years (Pappas \& Woodside, 2021).

Qualitative research, or case-oriented research, is often critiqued for failing to incorporate formality and rigour into comparisons and for placing too great an emphasis on specific, individual cases (Rihoux \& Lobe, 2009). On the other hand, quantitative (variable-oriented) research, as the name suggests, arguably over-emphasises variables and fails to capture detailed analyses of cases, overlooking their specificities in favour of examining variations across cases (Rihoux \& Lobe, 2009). FsQCA integrates the features of both approaches. This enables fsQCA as a tool to recognise the diversity and heterogeneity of cases, in terms of their causally relevant conditions and contexts, by allowing cases to be compared as configurations (Fiss, 2011). As an established analytical tool for investigating the configurational nature of conditions (Delgosha et al., 2020; Fiss, 2011; Pappas, 2018; Pappas et al., 2020) fsQCA enabled an identification of the combinations of knowledge transfer conditions that led to success in ecosystem contexts.

Table 4 Final Reachability Matrix

\begin{tabular}{|c|c|c|c|c|c|c|c|c|c|}
\hline & $\begin{array}{l}\text { Type of } \\
\text { Knowled-ge }\end{array}$ & $\begin{array}{l}\text { Understandi- } \\
\text { ng }\end{array}$ & $\begin{array}{l}\text { Causal } \\
\text { Ambiguity }\end{array}$ & Trust & $\begin{array}{l}\text { Tie } \\
\text { Strength }\end{array}$ & $\begin{array}{l}\text { Cultural } \\
\text { Similarit-y }\end{array}$ & $\begin{array}{l}\text { Learning } \\
\text { Intent }\end{array}$ & $\begin{array}{l}\text { Absorpti-ve } \\
\text { Capacity }\end{array}$ & $\begin{array}{l}\text { Driving } \\
\text { power }\end{array}$ \\
\hline $\begin{array}{l}\text { Type of } \\
\text { Knowledge }\end{array}$ & 1 & 1 & $1^{*}$ & $1^{*}$ & 1 & 1 & 1 & 1 & 8 \\
\hline Understanding & 1 & 1 & 1 & 1 & $1^{*}$ & 1 & 1 & 1 & 8 \\
\hline $\begin{array}{l}\text { Causal } \\
\text { Ambiguity }\end{array}$ & 1 & 1 & 1 & 1 & 1 & 1 & 1 & 1 & 8 \\
\hline Trust & 1 & 1 & 1 & 1 & 1 & $1^{*}$ & $1 *$ & 1 & 8 \\
\hline Tie Strength & 1 & $1^{*}$ & 1 & 1 & 1 & $1^{*}$ & 1 & 1 & 8 \\
\hline $\begin{array}{l}\text { Cultural } \\
\text { Similarity }\end{array}$ & 1 & 1 & 1 & 1 & 1 & 1 & 1 & 1 & 8 \\
\hline Learning Intent & 1 & 1 & 1 & $1 *$ & $1^{*}$ & 1 & 1 & 1 & 8 \\
\hline $\begin{array}{l}\text { Absorptive } \\
\text { Capacity }\end{array}$ & 1 & 1 & 1 & 1 & 1 & 1 & 1 & 1 & 8 \\
\hline Dependence & 8 & 8 & 8 & 8 & 8 & 8 & 8 & 8 & \\
\hline
\end{tabular}


Table 5 Reachability and Antecedent Sets

\begin{tabular}{llll}
\hline Measure number & Reachability set & Antecedent set & Intersection \\
\hline 1 & $1,2,3,4,5,6,7,8$ & $1,2,3,4,5,6,7,8$ & $1,2,3,4,5,6,7,8$ \\
2 & $1,2,3,4,5,6,7,8$ & $1,2,3,4,5,6,7,8$ & $1,2,3,4,5,6,7,8$ \\
3 & $1,2,3,4,5,6,7,8$ & $1,2,3,4,5,6,7,8$ & $1,2,3,4,5,6,7,8$ \\
4 & $1,2,3,4,5,6,7,8$ & $1,2,3,4,5,6,7,8$ & $1,2,3,4,5,6,7,8$ \\
5 & $1,2,3,4,5,6,7,8$ & $1,2,3,4,5,6,7,8$ & $1,2,3,4,5,6,7,8$ \\
6 & $1,2,3,4,5,6,7,8$ & $1,2,3,4,5,6,7,8$ & $1,2,3,4,5,6,7,8$ \\
7 & $1,2,3,4,5,6,7,8$ & $1,2,3,4,5,6,7,8$ & 1 \\
8 & $1,2,3,4,5,6,7,8$ & $1,2,3,4,5,6,7,8$ & 1 \\
\hline
\end{tabular}

\subsubsection{Calibration}

FsQCA requires data to be transformed into 'fuzzy' sets, placing conditions on a continuous (fuzzy) scale ranging from 0 to 1 (Woodside, 2014). The calibration process informs values for full membership and non-membership within a set, as well as a maximum level of ambiguity. These values are selected according to substantive knowledge of the cases. Qualitative anchors within the scales were used to calibrate the conditions (Ordanini et al., 2014). In being an accepted approach to calibration (Ordanini et al., 2014; Pappas et al., 2016; Woodside, 2013) natural scale breakpoints were utilised to calibrate the fuzzy sets; as opposed to the direct method to calibration (Ragin, 2008) substantive knowledge of cases drove the calibration of conditions in this study, rather than sample means (Oyemomi et al., 2019). For this study, full membership for each of the conditions was outlined as 6 , the crossover point was 4.5 , and non-membership was 3 . The usage of 4.5 as a crossover point ensured that no cases were removed from the analysis, and is an accepted approach for calibration (Oyemomi et al., 2019; Tho \& Trang, 2015). This aligns with previous fsQCA research (Bacon et al., 2019a; Mikalef \& Pateli, 2017; Tho \& Trang, 2015) where data values and knowledge about cases drive the calibration of conditions, in line with the indirect method of calibration. Moreover, akin to Ordanini et al. (2014), Tho and Trang (2015) and Mikalef and Pateli (2017), we raised the threshold for non-membership to 3 in order to account for data skewness. Due to a participant response bias towards the higher end of the likert-scale, a nonmembership threshold of 3 enabled a greater amount of responses to be categorised as being 'out' of the set, hence accounting for the response bias. All empirical data was skewed to varying degrees and raising the non-membership value to 3 provided an acceptable solution to this. Coverage and consistency scores for solutions were also improved when using 3 as the threshold for non-membership.

The outcome measure was assessed using five separate Likert-scales corresponding to the five identified components of knowledge transfer success. As fsQCA requires a single value for the outcome, the five scale responses were converted into a single value through the following procedure. Firstly, responses to each individual component were averaged. Next, if each individual response to each component was higher than the average, then the response was re-coded as a 1 ; if below, a 0 . Each of the five re-coded values for each participant were then averaged to result in a final score of between 0 and 1 . As the data for the outcome condition was collected differently from the other conditions, as per Bacon et al. (2019a), the outcome variable needed to be calibrated differently than the condition (independent) variables, as observed in existing fsQCA studies that calibrate the outcome differently to the causal conditions (Veri, 2019; Veríssimo, 2016; Wang, 2016); Hence, for membership within the outcome, 0.8 was selected as full membership, the crossover point as 0.5 , and non-membership as 0.2 .

Previous research within this domain (Bacon et al., 2019a, b) presents contrarieties in terms of the calibration of the conditions 'type of knowledge' and 'understanding'. Bacon et al. (2019a) calibrate knowledge type and understanding as a single condition, without considering the influence of either tacit or explicit knowledge upon the degree of understanding. Bacon et al. (2019b) calibrate knowledge type and understanding as separate conditions, with tacit and explicit knowledge calibrated as separate crisp sets ( $0 / 1$ membership) and understanding as a four-value fuzzy set. This paper extends the work of these authors, superimposing knowledge type and

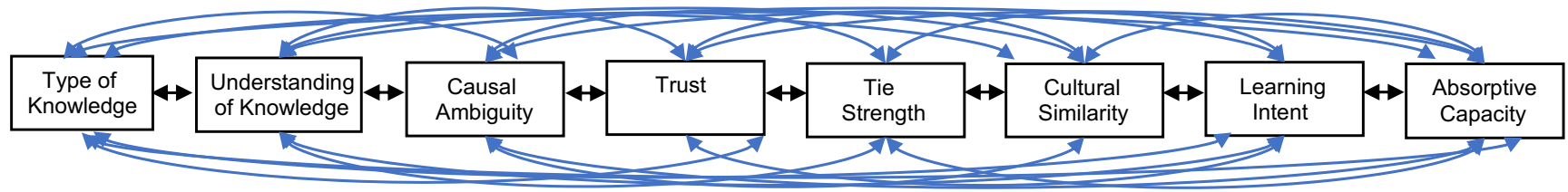

Fig. 2 ISM Digraph 
Table 6 Interview scales \& questions

\begin{tabular}{|c|c|c|c|c|}
\hline $\begin{array}{l}\text { Condition } \\
\text { characteristics }\end{array}$ & Condition & Adapted from & Initial questions \& scales & $\begin{array}{l}\text { Follow-up questions asked for } \\
\text { each condition (based on response } \\
\text { to initial question) }\end{array}$ \\
\hline \multirow[t]{2}{*}{$\begin{array}{l}\text { Knowledge } \\
\text { characteristics }\end{array}$} & $\begin{array}{l}\text { Knowledge } \\
\text { Type \& } \\
\text { Understan- } \\
\text { ding }\end{array}$ & Simonin (2004) & $\begin{array}{l}\text { Would you say the knowledge you gained from your } \\
\text { ecosystem partner was information highly personal and } \\
\text { experiential, specific to your ecosystem partner (tacit)? Or } \\
\text { was it more technical knowledge, in the form of perhaps } \\
\text { manuals or policies (explicit)? } \\
\text { Please rate your level of understanding of the knowledge you } \\
\text { received, ranging from low level to high level. }\end{array}$ & $\begin{array}{l}\text { Could you please tell me a bit } \\
\text { more about why that is? } \\
\text { Why didn't you choose a } \\
\text { lower/higher rating? } \\
\text { Can you give me an example of } \\
\text { this? } \\
\text { I'd like to hear more about... }\end{array}$ \\
\hline & $\begin{array}{l}\text { Causal } \\
\text { Ambiguity }\end{array}$ & $\begin{array}{c}\text { Bhagat et al. } \\
(2002)\end{array}$ & $\begin{array}{l}\text { To what extent do you believe that the origins of the } \\
\text { information gained from your ecosystem partner were } \\
\text { unambiguous, ranging from unclear to clear? }\end{array}$ & \\
\hline \multirow[t]{3}{*}{$\begin{array}{l}\text { Relationship } \\
\text { characteristics }\end{array}$} & Trust & $\begin{array}{l}\text { Mazloomi } \\
\text { Khamseh } \\
\text { and Jolly } \\
\text { (2008) }\end{array}$ & $\begin{array}{l}\text { To what extent do you believe that you have a trustworthy } \\
\text { relationship with your ecosystem partner, ranging from } \\
\text { untrustworthy to trustworthy? }\end{array}$ & \\
\hline & Tie Strength & $\begin{array}{c}\text { Al-Salti and } \\
\text { Hackney } \\
(2011)\end{array}$ & $\begin{array}{l}\text { To what extent do you believe that you have a strong } \\
\text { relationship with your ecosystem partner, ranging from } \\
\text { weak to strong? }\end{array}$ & \\
\hline & $\begin{array}{l}\text { Cultural } \\
\quad \text { Similarity }\end{array}$ & $\begin{array}{l}\text { Van Wijk et al. } \\
\text { (2008) }\end{array}$ & $\begin{array}{l}\text { To what extent do you believe that your organisation } \\
\text { possesses an organisational culture similar to that of your } \\
\text { ecosystem partner, ranging from dissimilar to similar? }\end{array}$ & \\
\hline \multirow[t]{2}{*}{$\begin{array}{l}\text { Organisational } \\
\text { characteristics }\end{array}$} & $\begin{array}{c}\text { Learning } \\
\text { Intent }\end{array}$ & Simonin (2004) & $\begin{array}{l}\text { To what extent do you believe that your organisation } \\
\text { possesses a willingness to learn new knowledge, ranging } \\
\text { from unwilling to willing? }\end{array}$ & \\
\hline & $\begin{array}{r}\text { Absorptive } \\
\text { Capacity }\end{array}$ & $\begin{array}{l}\text { Easterby-Smith } \\
\text { et al. (2008) }\end{array}$ & $\begin{array}{l}\text { To what extent do you believe that your organisation absorbs } \\
\text { and acquires new knowledge, ranging from unabsorptive to } \\
\text { absorptive? }\end{array}$ & \\
\hline
\end{tabular}

Adapted from Bacon et al. (2019a)

understanding into a macro-condition renamed 'knowledge type \& understanding' through collectively averaging the values for tacit knowledge, explicit knowledge, and understanding to deduce whether the type of knowledge affects its understanding. This follows Ragin and Fiss' (2018) 'averaging' approach to generating a macro-condition within

Table 7 Scales for outcome measure

Outcome measure: knowledge transfer success
Please rate the extent of your agreement on the following scales, ranging from strongly disagree (1) to strongly agree (7):

The knowledge transferred from our ecosystem partner was transferred in a resourceful manner, utilising minimal resources.

The knowledge produced a measurable outcome.

The knowledge was effectively absorbed within our organisation.

As an organisation, we utilised that knowledge in a beneficial manner.

We are satisfied with the knowledge received by our ecosystem partner. 
fsQCA (Ragin \& Fiss, 2018). This condition was hence calibrated in a similar way to the outcome, with 0.8 constituting full membership, 0.5 as a crossover point, and 0.3 as full nonmembership. Consequently, the degree to which the knowledge was understood in terms of its typology is collectively termed 'knowledge type \& understanding' in this study. While this condition technically encompasses two variable names in one, the constructs remain highly interrelated (Cummings \& Teng, 2003; Harlow, 2008; Koskinen, 2000) with extant fsQCA research combining two separate constructs into a single variable name (see, for example, Pappas et al., 2017). This improved consistency and coverage scores for the fsQCA results and arguably offered a more comprehensive calibration of how knowledge characteristics affect transfer success. Hence, fsQCA was performed on seven conditions: knowfz (knowledge type \& understanding), caufz (causal ambiguity), trufz (trust), tiefz (tie strength), cultfz (cultural similarity), learnfz (learning intent) and acapfz (absorptive capacity).

\subsubsection{Stages in fsQCA}

The first stage of fsQCA is to utilise set measures to generate a data matrix known as a truth table. The truth table displays all logically possible combinations of conditions (Schneider \& Wagemann, 2012). A truth table possesses $2^{k}$ rows, where $\mathrm{k}$ is the number of causal conditions employed within the analysis (Fiss, 2011). Each row within the truth table is associated with a specific number of conditions; the truth table lists all logically possible combinations of conditions (Ragin, 2008) even if there is no case data that empirically demonstrates a given combination. Having configurations without empirical instances is referred to as limited diversity (Fiss, 2011): rows without cases are termed logical remainders.

In the second stage, rows within the truth table are reduced to facilitate the analysis (Fiss, 2011). The first step in reducing the rows is to set a benchmark for the minimum number of cases required for a solution to be considered (Fiss, 2011). According to Ragin (2008), for small-N samples (e.g. 1-50 cases) a threshold of 1 is appropriate. Next, the consistency of each solution needs to be assessed. Consistency refers to the degree to which solution terms and the solution as a whole are subsets of the outcome (Ragin, 2008). For this study, a consistency threshold of 0.76 was selected, surpassing the recommended 0.75 threshold (Ragin, 2008).

Analysis of the truth table involves the examination of case distribution across the property space, and a systematic identification of the causal conditions sufficient for the outcome of interest to occur (Greckhamer et al., 2008). The analysis allows an identification of combinations of conditions that are subsets or supersets of the outcome, thus arriving at sufficient or necessary conditions (Schneider \& Wagemann, 2012). The combination of causal conditions will result in three solutions being produced for each analysis. Ragin (2008) summarises the three solutions. The first is a 'complex' solution, where no logical remainders (rows without cases) have been included. The second is a parsimonious solution, where logical remainders may be used, without any consideration of their empirical possibility. The final solution is the intermediate, which supposedly bridges the two: the intermediate solution only considers logical remainders that are plausible, where plausibility is judged using the researcher's relevant theoretical and empirical knowledge.

This study utilises the approach outlined by Fiss (2011) to display the final fsQCA results, whereby the parsimonious and intermediate solutions are awarded utmost prevalence. Through observing these solutions, core and peripheral conditions can be identified. Core conditions are present within both the parsimonious and intermediate solutions, and hence arguably retain high causal essentiality: peripheral conditions are solely present within the intermediate solution and are therefore deemed less essential.

\section{3 fsQCA Results}

Table 8 displays the results arising from fsQCA, demonstrating six solutions for the outcome of success. The first solution combines the presence of knowledge type \& understanding, trust, tie strength, and learning intent, with the absence of absorptive capacity, and with causal ambiguity and cultural similarity as redundant conditions. Solution Two combines the presence of knowledge type \& understanding, causal ambiguity, tie strength, cultural similarity, and learning intent, with trust and absorptive capacity as redundant conditions. Solution Three combines the presence of causal ambiguity, trust, tie strength, learning intent and absorptive capacity, with the absence of cultural similarity and the redundancy of knowledge type \& understanding. Solution Four combines the presence of knowledge type \& understanding, causal ambiguity, trust, tie strength, and absorptive capacity, with the absence of cultural similarity, and the redundancy of learning intent. Solution Five combines the absence of knowledge type $\&$ understanding, trust, cultural similarity, learning intent and absorptive capacity, with the presence of causal ambiguity and tie strength. Finally, Solution Six combines the absence of causal ambiguity, trust, tie strength, and cultural similarity, with the presence of knowledge type \& understanding, learning intent, and absorptive capacity.

Across all six solutions, core conditions (present within both the parsimonious and intermediate solutions) are Acapfz (Solutions 3, 4 and 6), the causal configurations Tiefz*Learnfz (Solutions 1,2 and 3) and the causal configuration Tiefz* $\sim$ Cultfz (Solutions 3, 4 and 5). Note that the absence of cultural similarity is a core condition in Solutions 3, 4 and 5 , but only when combined with the presence of tie strength. Overall solution coverage is high at 0.83 , indicating 
Table 8 FsQCA Results

Solution

\begin{tabular}{|c|c|c|c|c|c|c|}
\hline \multirow[b]{2}{*}{ Configuration } & \\
\hline & 1 & 2 & 3 & 4 & 5 & 6 \\
\hline Knowfz & - & - & & - & $\otimes$ & - \\
\hline Caufz & & - & - & - & - & $\otimes$ \\
\hline Trufz & - & & - & - & $\otimes$ & $\otimes$ \\
\hline Tiefz & $\bullet$ & $\bullet$ & $\bullet$ & $\bullet$ & $\bullet$ & $\otimes$ \\
\hline Cultfz & & • & $\otimes$ & $\otimes$ & $\otimes$ & $\otimes$ \\
\hline Learnfz & $\bullet$ & $\bullet$ & $\bullet$ & & $\otimes$ & • \\
\hline Acapfz & $\otimes$ & & $\bullet$ & $\bullet$ & $\otimes$ & $\bullet$ \\
\hline Raw coverage & 0.389518 & 0.298867 & 0.421624 & 0.389518 & 0.0524079 & 0.0764872 \\
\hline Unique coverage & 0.160057 & 0.0868744 & 0.0642115 & 0.0321056 & 0.0321057 & 0.0217185 \\
\hline Consistency & 0.811209 & 0.954751 & 0.843248 & 0.860271 & 0.965217 & 0.931034 \\
\hline \multicolumn{4}{|c|}{ Overall solution coverage } & \multicolumn{3}{|l|}{0.831445} \\
\hline \multicolumn{4}{|c|}{ Overall solution consistency } & \multicolumn{3}{|l|}{0.861125} \\
\hline
\end{tabular}

that the six solutions account for a large proportion of the outcome. Overall solution consistency is 0.86 , surpassing the recommended 0.75 threshold and confirming that the solutions represent a relatively consistent subset of the outcome (Ragin, 2006) - although perfect consistency (1) is not achieved.

\subsubsection{Predictive Validity}

FsQCA can also be used to test for predictive validity, an important procedure to demonstrate whether a model is able to predict equally well the same dependent variable on a different sample (Gigerenzer \& Brighton, 2009). Testing for predictive validity using this procedure is an established technique in fsQCA research (e.g. Mikalef \& Pateli, 2017; Tho \& Trang, 2015). To test for predictive validity in fsQCA, the sample is divided into two subsamples. Truth table algorithms are ran for each sample: then, each solution obtained is calibrated as a variable, and truth table analysis is ran on the second sample. Each of these solutions obtained represents a 'model' that needs to be calibrated against the outcome (knowledge transfer success). More details on predictive validity are outlined in Pappas et al. (2016) and Pappas and Woodside (2021). Table 9 displays the configurations obtained from the first subsample. The new variable is plotted against the outcome (knowledge transfer success) using the holdout sample (Fig. 3): results from this analysis demonstrate high consistency $(0.80)$ and coverage $(0.32)$, similar to the scores obtained from subsample 1 (Table 9). These consistency and coverage scores are hence appropriate and comparable to extant literature utilising predictive validity through fsQCA (e.g. Mikalef \& Pateli, 2017; Pappas, 2018; Robinot et al., 2021). Predictive tests for all models suggest that the highly consistent models obtained from both sub-samples have high predictive ability (Pappas, 2018). Further results are available on request.

\section{Discussion}

Results from both phases of analysis offer significant insights into knowledge transfer success within innovation ecosystems. With the principle of transitivity causing all conditions to occupy the same level within the resultant hierarchy, condition co-dependency was revealed. In response to the first research question of this investigation, this confirms the notion that no singular condition carried greater prominence for knowledge transfer success, with all conditions instead being interrelated. Once confirming that all conditions were interrelated, fsQCA afforded configurational insights into knowledge transfer success: in response to the second research question for this investigation, we can deduce that relationship, knowledge and organisational-related characteristics combine in six mutually exclusive, distinct pathways to knowledge transfer success. Solutions One and Three display knowledge type \& understanding as present in Solution One, compared with the presence of causal ambiguity in Solution Three, indicating that at least one knowledge characteristic needs to be present within these partnership types. Interestingly, causal ambiguity is present in Solutions Three, Four and Five where tie strength and the absence of cultural similarity are core conditions, indicating that this knowledge characteristic retains a clear relationship with the causal configuration tiefz $\sim$ cultfz. Tie strength and the absence of cultural similarity manifest as a core causal configuration in Solution Three; as previous findings suggest an interrelation between the presence of both these conditions (Lizardo, 2006) further studies could obtain additional insights into why the absence of 
Table 9 Predictive Validity

\begin{tabular}{|c|c|c|c|}
\hline Models from Subsample 1 & Raw coverage & Unique coverage & Consistency \\
\hline Caufz $*$ Trufz $^{*}$ Tiefz $^{*} \sim$ Cultfz*Learnfz*Acapfz & 0.510818 & 0.0667921 & 0.795022 \\
\hline Caufz*Trufz*Tiefz* ${ }^{*} \sim$ Cultfz*Acapfz*Knowfzz & 0.507996 & 0.0639699 & 0.794118 \\
\hline Caufz*Trufz*Tiefz*Cultfz*Learnfz*Knowfzz & 0.313264 & 0.107244 & 0.988131 \\
\hline Caufz*Tiefz*Cultfz*Learnfz*Acapfz*Knowfzz & 0.249294 & 0.0432737 & 0.98513 \\
\hline Overall solution coverage & & 0.789276 & \\
\hline Overall solution consistency & & 0.856997 & \\
\hline
\end{tabular}

cultural similarity and the presence of tie strength retain high causal essentiality with knowledge transfer success. Tie strength also manifests as a core causal configuration when combined with learning intent, confirming extant findings regarding the relationship between these conditions (Xie et al., 2015). With Solutions One and Three differing on absorptive capacity manifesting as core within Solution Three only, it may be the case that the absence of cultural similarity affects the causal essentiality of absorptive capacity, indicating that organisations were able to absorb and assimilate acquired knowledge despite greater cultural distance between their ecosystem partner. Hence, it may be deduced that differences between parties benefitted knowledge absorption. This is also the case within Solutions Four and Six, where absorptive capacity is core, and cultural similarity is absent. Along with Solution Two, Solution Four confirms the association between knowledge-related characteristics (Al-Salti \& Hackney, 2011; Pak \& Park, 2004; Simonin, 1999) with both characteristics present. As trust differs on redundancy (Solution Two) and presence (Solution Four), and cultural similarity differs on presence (Solution Two) and absence (Solution Four) within these solutions, it can be inferred that at least two relationshiprelated characteristics require combination with knowledge-related characteristics in these partnership types. Nonetheless, tie strength maintains high causal essentiality with the outcome, again reinforcing the significance of this condition for knowledge transfer success. Whilst organisational characteristics further differ on redundancy and presence, their presence as core conditions suggests that as long as an organisation is motivated to learn, or is able to disseminate knowledge internally, fostering a strong relationship with their ecosystem partner ensures successful knowledge exchange.

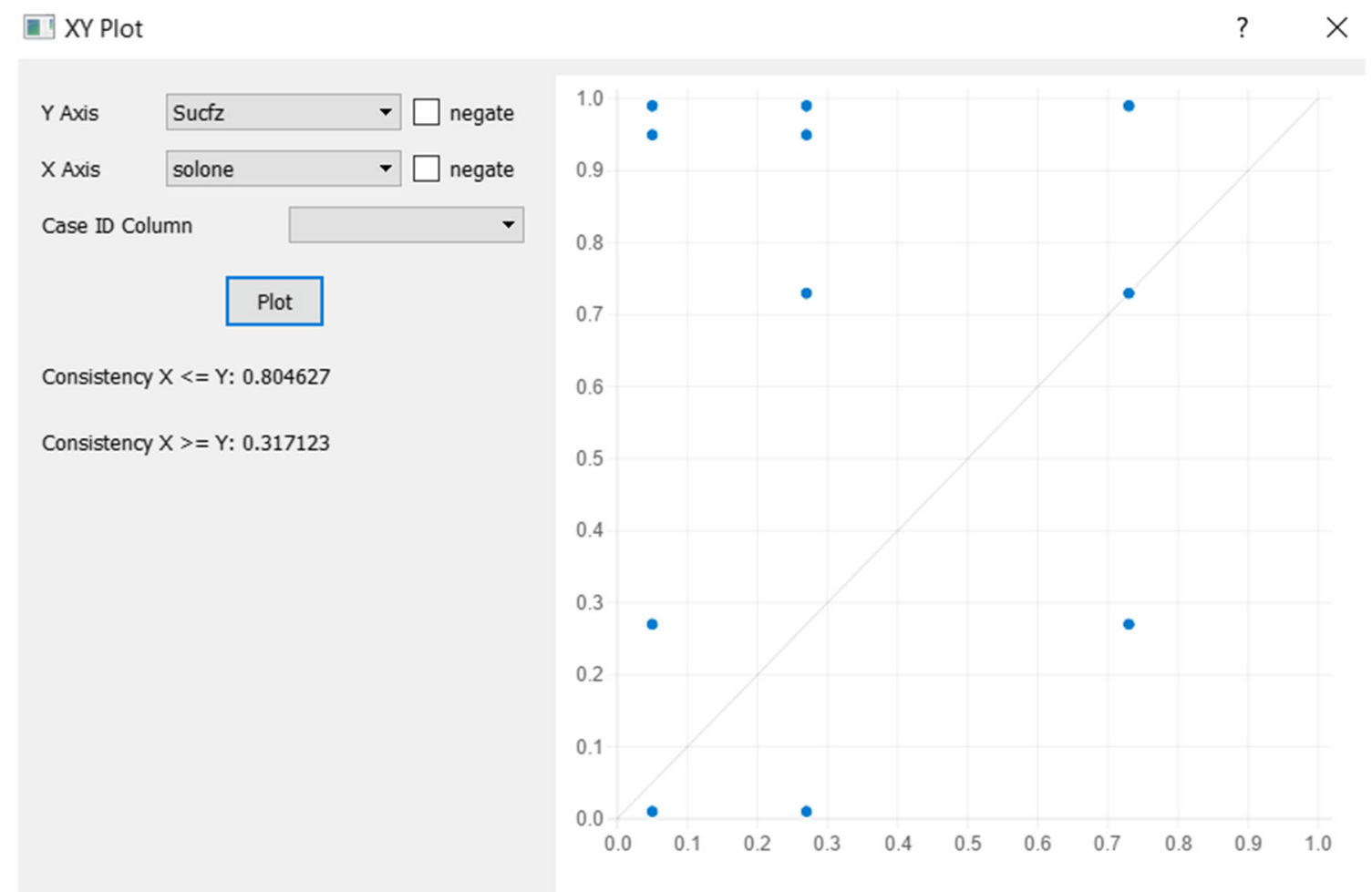

Fig. 3 Predictive Validity 
Solutions Five and Six display similar discrepancies with knowledge-related characteristics, differing on the absence of knowledge type \& understanding in Solution Five, and causal ambiguity in Solution Six, once again confirming that at least one knowledge characteristic is needed for knowledge transfer success. With trust and cultural similarity exhibiting absence, and tie strength only manifesting as present in Solution Five, it can be inferred that tie strength remains a highly significant antecedent of knowledge transfer (Al-Salti \& Hackney, 2011; Cummings \& Teng, 2003; Inkpen \& Tsang, 2005; Ko et al. 2005; Levin \& Cross, 2004; Narteh, 2008; Rejeb-Khachlouf et al., 2011; Van Wijk et al., 2008; Wood, Dibben, \& Meira, 2016; Wulf \& Butel, 2017; Xie et al., 2016). As learning intent only exhibits high causal essentiality when combined with tie strength, the relationship between these conditions is further evidenced in Solutions Five and Six when the absence of either condition results in these conditions becoming peripheral. Nonetheless, absorptive capacity demonstrates high causal essentiality in Solution Six, indicating that this condition may be a way to ensure success in these solution types, confirming its significance as a further antecedent of knowledge transfer (Al-Salti \& Hackney, 2011; Chen, 2004; Cummings \& Teng, 2003; Lawson \& Potter, 2012; Martinkenaite, 2011; Narteh, 2008; Pak \& Park, 2004; Rejeb-Khachlouf et al., 2011; Van Wijk et al., 2008). However, despite these conditions retaining high causal essentiality with the outcome, tie strength only manifests as core when combined with other causal conditions, and absorptive capacity is only a core condition within half of the solutions.

According to the two approaches for analysing necessity in fsQCA as outlined by Dul (2016), we follow the second approach, where analyses of sufficiency are conducted first to identify common single conditions that form part of all sufficient configurations as likely candidates for necessary conditions, which are then confirmed through analyses of necessity. If a single condition is part of a larger number of sufficient configurations then it is more likely to be necessary (Dul, 2016, p.1519). As no condition was present across all solutions, nor exceeded the 0.9 threshold during the necessary conditions analysis, it was determined that no condition was necessary, and that combinations of conditions were sufficient for the outcome. Results of this necessary conditions analysis have been excluded from this paper due to space limitations but are available on request.

With previous studies accentuating condition interrelationships including knowledge type and learning intent (Cummings \& Teng, 2003; Pérez-Nordtvedt et al., 2008) understanding and cultural similarity (Al-Salti \& Hackney, 2011; Evangelista, 2007; Szulanski et al. 2004; Van Wijk et al., 2008) and trust and tie strength (Inkpen \& Tsang, 2005; Wulf \& Butel, 2017: see Section 3.1 for a complete list), insights into the most prevalent knowledge transfer conditions, and whether such relationships were observed across all conditions and characteristic groupings, remained absent from the extant literature. While these interrelations are observed in existing studies, indicating a strong likelihood that, again using the principles of transitivity, the conditions were likely to be interrelated, limited research had developed insights into the configurational nature of knowledge transfer success in the context of innovation ecosystems. Despite some conditions being more heavily cited within existing studies (e.g. trust), results of both ISM and fsQCA reveal the interrelated nature of all conditions, albeit combining in multiple and distinct ways to contribute to success.

\section{Conclusion}

\subsection{Theoretical Implications}

This research retains a number of important theoretical implications. Firstly, this investigation contributes to the existing ISM literature that identifies success factors for a given outcome (Sahney, 2008; Singh et al., 2007; Tripathy et al., 2013): while ISM has been widely applied to a variety of research areas (Alawamleh \& Popplewell, 2011; Hasan et al., 2007; Mandal \& Deshmukh, 1994; Nishat Faisal et al., 2006; Pfohl et al., 2011; Raj et al., 2008) the application of ISM to the analysis of knowledge transfer success across innovation ecosystems remains limited (Bacon et al., 2019b). As all conditions in the ISM model had equal driving and dependence power, all conditions were coined 'linkage' elements in that they are affected by all other conditions and influence all other conditions. This retains a key implication for the knowledge transfer literature in identifying that all these conditions are important constituents of knowledge transfer success as they all influence one another: as such, the outcome cannot be analysed sufficiently without consideration of all these elements. In terms of the implications of the ISM model, we can deduce that not all ISM models are able to impose a hierarchy upon the conditions. Sometimes complex outcomes such as knowledge transfer success are unable to be reduced to a hierarchical model and this serves to further emphasise that knowledge transfer success is a complex phenomena, grounded upon multiple and interrelated elements.

Synthesis of both phases of analysis signifies that knowledge transfer success is grounded upon combinations of conditions. Previous review articles have cited a multitude of factors which facilitate inter-organisational knowledge transfer (e.g. Charband \& Navimipour, 2016; Pérez-Nordtvedt et al., 2008): this investigation evidences the equifinal nature of knowledge transfer success through the presence of six solutions, confirming previous findings regarding the interrelations between conditions, evidenced through their moderating effects (Van Wijk et al., 2008) and contributing to the 
existing body of research that discusses antecedents of success (Al-Salti \& Hackney, 2011; Cummings \& Teng, 2003; Hasty et al., 2006). While existing studies (Lawson \& Potter, 2012; Miller et al., 2016) have investigated the influence of multiple conditions on knowledge transfer as an outcome, the configurational significance of these conditions remains relatively undiscussed within existing research; both ISM and fsQCA findings reveal the interrelated nature of the conditions as elements of knowledge transfer success, emphasising that such a significance should not be overlooked. Scholars should therefore be mindful of the highly interrelated nature of these conditions when pursuing similar research opportunities: future research should demonstrate an awareness that these conditions appear to manifest as configurational aspects of this outcome. Moreover, fsQCA results reveal multiple, mutually exclusive pathways of sufficient configurations, indicating that no single condition is responsible for this outcome: thus, knowledge transfer success cannot be reduced to a singular condition. Specific conditions retain higher causal essentiality with knowledge transfer success, indicating that they are core for knowledge transfer success. Such conditions are absorptive capacity in Solutions 3,4, and 6; tie strength and learning intent in Solutions 1, 2 and 3; and tie strength combined with the absence of cultural similarity in Solutions 3, 4 and 5. Future studies should hence delve further into the configurational nature of these conditions.

This investigation is one of the first, to the best of our knowledge, to amalgamate ISM and fsQCA as analytical techniques. FsQCA is often combined with other quantitative techniques such as Structural Equation Modelling (Fang et al., 2016; Mikalef \& Pateli, 2017; Tho \& Trang, 2015) or regression analyses (Fiss et al., 2013; Ho et al., 2016). ISM is frequently combined with another 'fuzzy' analytical tools such as fuzzy MICMAC analysis (Dubey \& Ali, 2014; Gorane \& Kant, 2013; Khan \& Haleem, 2012; Pfohl et al., 2011; Soti et al., 2011) or fuzzy analytic network processes (Lee et al., 2011). Synthesising these techniques enabled a more comprehensive examination into the knowledge transfer conditions, resulting in a more nuanced and holistic analysis that emphasised their interconnected nature, whilst contributing to the management literature through offering a potential combination of analytical techniques for future studies. Whilst the purpose of ISM was to identify whether certain conditions retained greater importance for knowledge transfer success, the resultant model demonstrated that all conditions remained interrelated, and hence, the combination of these techniques served to emphasise the interdependencies between the knowledge transfer conditions. With both ISM (Singh et al., 2003) and fsQCA (Ragin, 2008) being grounded upon the principles of complexity, integration of the techniques afforded a reconciliation of results through deconstructing knowledge transfer success across innovation ecosystems into its, albeit interrelated, elements.
In order to achieve digital transformation, the processes by which public and private organisations interact, cooperate and collaborate within an ecosystem require evolution and change (Pappas et al., 2018). This paper generates a more structured analysis of processes underlying digital transformation across multiple ecosystems, a necessary insight (Riasanow et al., 2020) outlining the interrelated nature of knowledge transfer conditions and providing solutions that will benefit all ecosystem actors (Pappas et al., 2018). This paper hence contributes to extant digital transformation literature through providing a comprehensive analysis of the interdependencies underlying innovation ecosystems, achieved through utilising a mixedmethod approach.

\subsection{Managerial Implications}

Alongside theoretical implications, this investigation provides managerial implications for practitioners engaging in an ecosystem approach. Whilst both the ISM and fsQCA results reveal the interrelations between the conditions, there are some configurational elements of the fsQCA solutions that manifest as core, indicating strong causal essentiality with the outcome (Fiss, 2011). While it is important to recognise that these conditions formulate a configurational element of a solution, the fact that they are core means that practitioners should consider implementing strategies to ensure their presence or absence. Absorptive Capacity manifests as a core condition across three of the solutions: because this condition is an organisational construct, it is down to the individual firm to improve their absorptive capacity. Organisations should hence increase opportunities for knowledge integration, such as sharing knowledge through social interactions within the workplace (Lee \& $\mathrm{Wu}, 2010$ ). With tie strength manifesting as part of a core causal configuration, managers could consider utilising brokerage individuals or boundary spanners to foster and sustain strong ties, which are found to occur at an individual level (Michelfelder \& Kratzer, 2013). These individuals adopt a significant role in maintaining the strength of these partnerships; hence, firms could consider designating specific employees to adopt this role in order to cultivate and improve ecosystem relationships. As tie strength and learning intent are a core causal configuration in Solutions One, Two and Three, the combination of these conditions exhibits high causal essentiality. With inter-organisational interaction, a characteristic of strong partnerships (RejebKhachlouf et al., 2011), operating as a mechanism for increasing awareness of learning intent (Huang, 2010), ecosystem partners should not only engender a learning intent within their own organisation, but also generate an awareness of a partner's learning intent, to cultivate pathways to knowledge transfer success.

Alongside Tiefz*Learnfz, the absence of cultural similarity is also combined with tie strength as a core causal 
configuration. This indicates that the absence of cultural similarities is beneficial for success. Whilst complete distinction between cultures may be difficult to ensure success, it is the absence of similarity, and not complete diversity, that manifests as core within fsQCA. Thus, organisations could attempt to align their strategies with their ecosystem partner in terms of how their own organisation could offer something alternative within the partnership. A strong partnership facilitates this alignment, as observed by its combination with $\sim$ Cultfz, and firms should further be aware of the combinatory effects of these conditions.

\subsection{Limitations and Recommendations for Future Research}

As with all research, a number of limitations arise from this investigation: such limitations could be mitigated through future research. As no configuration exceeded the consistency threshold (0.75) when conducting fsQCA for the absence of the outcome, it can be confirmed that the findings are causally asymmetrical. The conditions for knowledge transfer success are associated with the presence of success alone, and as such, solutions for the absence of the outcome may be entirely distinct. This represents a research area requiring further attention, to shed light on how and why knowledge transfer is unsuccessful in these contexts, hence contributing towards a more holistic picture of success (Woodside, 2014).

This investigation further examines ecosystem partnerships involved in different stages of the innovation process. These variances between partnership stages may hence have exerted unwanted effects upon the analysis: particularly regarding the relationship characteristics, the stage of the innovation process may have affected whether certain conditions were present or indeed absent. It would hence be beneficial for future studies to ascertain whether these conditions change depending upon the stage of the innovation process: adopting comparative methodologies such as fsQCA would be appropriate.

While this investigation has examined seven knowledge transfer conditions and their impact upon success, their application to other inter-organisational contexts comprises an interesting avenue for future research. Platform-based ecosystems, crowdsourcing networks, and communities formulate important network-level contexts for further research (Bogers et al., 2017). The conceptual framework applied within this investigation provides a theoretical foundation for such future research. Moreover, whilst this paper ascertains the configurational nature of knowledge transfer conditions, it could be the case that additional conditions could contribute to knowledge transfer success within innovation ecosystems. This is further reflected in the ISM model where one level is observed, potentially indicating that further conditions could exert an influence upon knowledge transfer success, and the inclusion of such conditions would impose a greater degree of structure on this model. The conditions selected for this study were theoretically validated through a literature review of extant knowledge transfer literature (Bacon et al., 2019a) and were empirically validated through the expert consensus obtained in the second study conducted in this research. However, future studies could conduct a solely qualitative, exploratory study to examine whether additional conditions are perceived to affect knowledge transfer success by ecosystem partners.

\subsection{Concluding Remarks}

This investigation has presented an empirical, two-phase investigation into knowledge transfer success across innovation ecosystems. The configurational nature of the conditions reinforces that the complex construct of success is grounded upon combinations of knowledge transfer conditions. Key takeaways from this investigation accentuate that organisations can mould their knowledge transfer practices to one of the solution typologies, as well as cultivating the presence of core conditions to facilitate the process. Moreover, through combining knowledge-, firm- and relationship-related characteristics, organisations can maintain greater confidence that information will be exchanged effectively with their ecosystem partners.

Open Access This article is licensed under a Creative Commons Attribution 4.0 International License, which permits use, sharing, adaptation, distribution and reproduction in any medium or format, as long as you give appropriate credit to the original author(s) and the source, provide a link to the Creative Commons licence, and indicate if changes were made. The images or other third party material in this article are included in the article's Creative Commons licence, unless indicated otherwise in a credit line to the material. If material is not included in the article's Creative Commons licence and your intended use is not permitted by statutory regulation or exceeds the permitted use, you will need to obtain permission directly from the copyright holder. To view a copy of this licence, visit http://creativecommons.org/licenses/by/4.0/.

\section{References}

Abrams, L. C., Cross, R., Lesser, E., \& Levin, D. Z. (2003). Nurturing interpersonal trust in knowledge-sharing networks. Academy of Management Perspectives, 17(4), 64-77. https://doi.org/10.5465/ ame.2003.11851845.

Adner, R., \& Kapoor, R. (2010). Value creation in innovation ecosystems: How the structure of technological interdependence affects firm performance in new technology generations. Strategic Management Journal, 31(3), 306-333. https://doi.org/10.1002/ smj.821.

Alawamleh, M., \& Popplewell, K. (2011). Interpretive structural modelling of risk sources in a virtual organisation. International Journal of Production Research, 49(20), 6041-6063. https://doi.org/10.1080/ 00207543.2010.519735. 
Al-Hindawe, J. (1996). Considerations when constructing a semantic differential scale. La Trobe papers in linguistics, 9(7), 1-9.

Al-Salti, Z., \& Hackney, R. (2011). Factors impacting knowledge transfer success in information systems outsourcing. Journal of Enterprise Information Management, 24(5), 455-468. https://doi.org/10.1108/ 17410391111166521.

Ambos, T. C., \& Ambos, B. (2009). The impact of distance on knowledge transfer effectiveness in multinational corporations. Journal of International Management, 15(1), 1-14. https://doi.org/10.1016/j. intman.2008.02.002.

Appio, F. P., Lima, M., \& Paroutis, S. (2018). Understanding smart cities: Innovation ecosystems, technological advancements, and societal challenges. Technological Forecasting and Social Change, 142, 1-14. https://doi.org/10.1016/j.techfore.2018.12.018.

Azevedo, S., Carvalho, H., \& Cruz-Machado, V. (2013). Using interpretive structural modelling to identify and rank performance measures: An application in the automotive supply chain. Baltic Journal of Management, 8(2), 208-230. https://doi.org/10.1108/ 17465261311310027.

Bacon, E., Williams, M. D., \& Davies, G. H. (2019a). Recipes for success: Conditions for knowledge transfer across open innovation ecosystems. International Journal of Information Management, 49, 377-387. https://doi.org/10.1016/j.ijinfomgt.2019.07.012.

Bacon, E., Williams, M., \& Davies, G. H. (2019b). Prioritising knowledge transfer conditions for innovation ecosystems: A mixedmethod approach. In I. Pappas, P. Mikalef, Y. Dwivedi, L. Jaccheri, J. Krogstie, \& M. Mäntymäki (Eds.), Digital transformation for a sustainable society in the 21st century: Lecture notes in computer science (pp. 747-758). Springer.

Becerra, M., Lunnan, R., \& Huemer, L. (2008). Trustworthiness, risk, and the transfer of tacit and explicit knowledge between alliance partners. Journal of Management Studies, 45(4), 691-713. https://doi. org/10.1111/j.1467-6486.2008.00766.x.

Bhagat, R. S., Kedia, B. L., Harveston, P. D., \& Triandis, H. C. (2002). Cultural variations in the cross-border transfer of organizational knowledge: An integrative framework. Academy of Management Review, 27(2), 204-221. https://doi.org/10.5465/amr.2002. 6588000.

Bogers, M. (2011). The open innovation paradox: Knowledge sharing and protection in R\&D collaborations. European Journal of Innovation Management, 14(1), 93-117. https://doi.org/10.1108/ 14601061111104715.

Bogers, M., Zobel, A. K., Afuah, A., Almirall, E., Brunswicker, S., Dahlander, L., Frederiksen, L., Gawer, A., Gruber, M., Haefliger, S., Hagedoorn, J., Hilgers, D., Laursen, K., Magnusson, M. G., Majchrzak, A., McCarthy, I. P., Moeslein, K. M., Nambisan, S., Piller, F. T., Radziwon, A., Rossi-Lamastra, C., Sims, J., \& ter Wal, A. L. J. (2017). The open innovation research landscape: Established perspectives and emerging themes across different levels of analysis. Industry and Innovation, 24(1), 8-40. https:// doi.org/10.1080/13662716.2016.1240068.

Brewer, J., \& Hunter, A. (2006). Foundations of multimethod research: Synthesizing styles. SAGE.

Cano-Kollmann, M., Cantwell, J., Hannigan, T. J., Mudambi, R., \& Song, J. (2016). Knowledge connectivity: An agenda for innovation research in international business. Journal of International Business Studies, 47, 255-262. https://doi.org/10.1057/jibs.2016.8.

Carayannis, E. G., \& Campbell, D. F. (2009). 'Mode 3'and'Quadruple Helix': Toward a 21 st century fractal innovation ecosystem. International Journal of Technology Management, 46(3-4), 201234. https://doi.org/10.1504/ijtm.2009.023374.

Châlons, C., \& Dufft, N. (2017). The role of IT as an enabler of digital transformation. In F. Abolhassan (Ed.), The drivers of digital transformation (pp. 13-22). Springer.

Chang, H. H., Tsai, Y. C., Fu, C. S., Chen, S. H., \& De Peng, Y. (2016). Exploring the antecedents and consequences of technology and knowledge integration mechanisms in the context of NPD. Information Systems Frontiers, 18(6), 1165-1189. https://doi.org/ 10.1007/s10796-016-9629-y.

Charband, Y., \& Navimipour, N. J. (2016). Online knowledge sharing mechanisms: A systematic review of the state of the art literature and recommendations for future research. Information Systems Frontiers, 18(6), 1131-1151. https://doi.org/10.1007/s10796-0169628-z.

Chen, C. J. (2004). The effects of knowledge attribute, alliance characteristics, and absorptive capacity on knowledge transfer performance. R\&D Management, 34(3), 311-321. https://doi.org/10. 1111/j.1467-9310.2004.00341.x.

Chesbrough, H. W. (2003). Open innovation: The new imperative for creating and profiting from technology. Harvard Business Press.

Chesbrough, H., Vanhaverbeke, W., \& West, J. (2006). Open innovation: Researching a new paradigm. Oxford University Press.

Chiang, Y. H., \& Hung, K. P. (2010). Exploring open search strategies and perceived innovation performance from the perspective of interorganizational knowledge flows. R\&D Management, 40(3), 292299. https://doi.org/10.1111/j.1467-9310.2010.00588.x.

Cummings, J. L., \& Teng, B. S. (2003). Transferring R\&D knowledge: The key factors affecting knowledge transfer success. Journal of Engineering and Technology Management, 20(1-2), 39-68. https://doi.org/10.1016/s0923-4748(03)00004-3.

Delgosha, M. S., Saheb, T., \& Hajiheydari, N. (2020). Modelling the asymmetrical relationships between digitalisation and sustainable competitiveness: A Cross-country Configurational analysis. Information Systems Frontiers, 1-21. https://doi.org/10.1007/ s10796-020-10029-0.

Dodgson, M. (1993). Organizational learning: A review of some literatures. Organization Studies, 14(3), 375-394. https://doi.org/10. 1177/017084069301400303.

Dubey, R., \& Ali, S. S. (2014). Identification of flexible manufacturing system dimensions and their interrelationship using total interpretive structural modelling and fuzzy MICMAC analysis. Global Journal of Flexible Systems Management, 15(2), 131-143. https://doi.org/ 10.1007/s40171-014-0058-9.

Dul, J. (2016). Identifying single necessary conditions with NCA and fsQCA. Journal of Business Research, 69(4), 1516-1523. https:// doi.org/10.1016/j.jbusres.2015.10.134.

Dwivedi, Y. K., Janssen, M., Slade, E. L., Rana, N. P., Weerakkody, V., Millard, J., Hidders, J., \& Snijders, D. (2017). Driving innovation through big open linked data (BOLD): Exploring antecedents using interpretive structural modelling. Information Systems Frontiers, 19(2), 197-212. https://doi.org/10.1007/s10796-016-9675-5.

Dwivedi, Y. K., Ismagilova, E., Rana, N. P., \& Raman, R. (2021). Social media adoption, usage and impact in business-to-business (B2B) context: A state-of-the-art literature review. Information Systems Frontiers, 1-23. https://oi.org/10.1007/s10796-021-10106-y.

Easterby-Smith, M., Lyles, M. A., \& Tsang, E. W. (2008). Interorganizational knowledge transfer: Current themes and future prospects. Journal of Management Studies, 45(4), 677-690. https://doi. org/10.1111/j.1467-6486.2008.00773.x.

Elia, G., Margherita, A., \& Passiante, G. (2020). Digital entrepreneurship ecosystem: How digital technologies and collective intelligence are reshaping the entrepreneurial process. Technological Forecasting and Social Change, 150, 119791. https://doi.org/10.1016/j. techfore.2019.119791.

Engler, J., \& Kusiak, A. (2011). Modeling an innovation ecosystem with adaptive agents. International Journal of Innovation Science, 3(2), 55-68. https://doi.org/10.1109/green.2010.5453799.

Evangelista, F. (2007). Acquiring tacit and explicit marketing knowledge from foreign partners in IJVs. Journal of Business Research, 60(11), 1152-1165. https://doi.org/10.1016/j.jbusres.2007.04.006.

Fang, S. C., Yang, C. W., \& Hsu, W. Y. (2013). Inter-organizational knowledge transfer: The perspective of knowledge governance. 
Journal of Knowledge Management, 17(6), 943-957. https://doi. org/10.1108/JKM-04-2013-0138.

Fang, J., Shao, Y., \& Wen, C. (2016). Transactional quality, relational quality, and consumer e-loyalty: Evidence from SEM and fsQCA. International Journal of Information Management, 36(6), 12051217. https://doi.org/10.1016/j.ijinfomgt.2016.08.006.

Ferreira, J. J., \& Teixeira, A. A. (2019). Open innovation and knowledge for fostering business ecosystems. Journal of Innovation \& Knowledge, 4(4), 253-255. https://doi.org/10.1016/j.jik.2018.10. 002.

Fiss, P. C. (2007). A set-theoretic approach to organizational configurations. Academy of Management Review, 32(4), 1180-1198. https:// doi.org/10.5465/amr.2007.26586092.

Fiss, P. C. (2011). Building better causal theories: A fuzzy set approach to typologies in organization research. Academy of Management Journal, 54(2), 393-420. https://doi.org/10.5465/amj.2011. 60263120.

Fiss, P, C., Sharapov, D., \& Cronqvist, L. (2013). Opposites attract? Opportunities and challenges for integrating large-N QCA and econometric analysis. Political Research Quarterly, 191-198. https://doi.org/10.1177/1065912912468269e.

Franco, M., \& Pinho, C. (2019). A case study about cooperation between university research Centres: Knowledge transfer perspective. Journal of Innovation \& Knowledge, 4(1), 62-69. https://doi.org/ 10.1016/j.jik.2018.03.003.

Gao, S., Xu, K., \& Yang, J. (2008). Managerial ties, absorptive capacity, and innovation. Asia Pacific Journal of Management, 25(3), 395412. https://doi.org/10.1007/s10490-008-9096-1.

Gigerenzer, G., \& Brighton, H. (2009). Homo heuristicus: Why biased minds make better inferences. Topics in Cognitive Science, 1(1), 107-143. https://doi.org/10.1111/j.1756-8765.2008.01006.x.

Gillespie, J. J., Privitera, G. J., \& Gaspero, J. (2019). Biopharmaceutical entrepreneurship, open innovation, and the knowledge economy. Journal of Innovation Management, 7(2), 59-77. https://doi.org/ 10.24840/2183-0606 007.0020005.

Giusti, J. D., Alberti, F. G., \& Belfanti, F. (2018). Makers and clusters. Knowledge leaks in open innovation networks. Journal of Innovation \& Knowledge, 5(1), 20-28. https://doi.org/10.1016/j. jik.2018.04.001.

Gonçalves, S. M., da Silva, R. V., \& Teixeira, N. (2019). Individual actors and embeddedness in business-to-business interactions. Industrial Marketing Management, 76, 181-191. https://doi.org/ 10.1016/j.indmarman.2018.08.006.

Gopalakrishnan, S., \& Bierly, P. (2001). Analyzing innovation adoption using a knowledge-based approach. Journal of Engineering and Technology Management, 18(2), 107-130. https://doi.org/10.1016/ s0923-4748(01)00031-5.

Gorane, S. J., \& Kant, R. (2013). Modelling the SCM enablers: An integrated ISM-fuzzy MICMAC approach. Asia Pacific Journal of Marketing and Logistics, 25(2), 263-286. https://doi.org/10.1108/ 13555851311314059.

Govindan, K., Azevedo, S. G., Carvalho, H., \& Cruz-Machado, V. (2015). Lean, green and resilient practices influence on supply chain performance: Interpretive structural modelling approach. International journal of Environmental Science and Technology, 12(1), 15-34. https://doi.org/10.1007/s13762-013-0409-7.

Greckhamer, T., Misangyi, V. F., Elms, H., \& Lacey, R. (2008). Using qualitative comparative analysis in strategic management research: An examination of combinations of industry, corporate, and business-unit effects. Organizational Research Methods, 11(4), 695-726. https://doi.org/10.1177/1094428107302907.

Harlow, H. (2008). The effect of tacit knowledge on firm performance. Journal of Knowledge Management, 12(1), 148-163. https://doi. org/10.1108/13673270810852458.

Hasan, M. A., Shankar, R., \& Sarkis, J. (2007). A study of barriers to agile manufacturing. International Journal of Agile Systems and
Management, 2(1), 1-22. https://doi.org/10.1504/ijasm.2007. 015679.

Hasty, B. K., Massey, A. P., \& Brown, S. A. (2006). Role-based experiences, media perceptions, and knowledge transfer success in virtual dyads. Group Decision and Negotiation, 15(4), 367-387. https:// doi.org/10.1007/s10726-006-9047-5.

He, Q., Gallear, D., \& Ghobadian, A. (2011). Knowledge transfer: The facilitating attribute in supply-chain partnerships. Information Systems Management, 28(1), 57-70. https://doi.org/10.1080/ 10580530.2011 .536114$.

Ho, J., Plewa, C., \& Lu, V. N. (2016). Examining strategic orientation complementarity using multiple regression analysis and fuzzy set QCA. Journal of Business Research, 69(6), 2199-2205. https:// doi.org/10.1016/j.jbusres.2015.12.030.

Hossain, M., \& Lassen, A. H. (2017). How do digital platforms for ideas, technologies, and knowledge transfer act as enablers for digital transformation? Technology Innovation Management Review, 7(9), 55-60. https://doi.org/10.22215/timreview/1106.

Hossain, M., Islam, K. Z., Sayeed, M. A., \& Kauranen, I. (2016). A comprehensive review of open innovation literature. Journal of Science \& Technology Policy Management, 7(1), 2-25. https://doi. org/10.1108/jstpm-02-2015-0009.

Huang, Y. T. (2010). Learning from cooperative inter-organizational relationships: the case of international joint venture. Journal of Business \& IndustrialMarketing, 25(6), 454-467. https://doi.org/ 10.1108/08858621011066044.

Iannacci, F., Fearon, C., \& Pole, K. (2020). From acceptance to adaptive acceptance of social media policy change: A set-theoretic analysis of B2B SMEs. Information Systems Frontiers, 1-18. https://doi.org/ 10.1007/s10796-020-09988-1.

Ilvonen, I., Thalmann, S., Manhart, M., \& Sillaber, C. (2018). Reconciling digital transformation and knowledge protection: A research agenda. Knowledge Management Research \& Practice, 16(2), 235-244. https://doi.org/10.1080/14778238.2018.1445427.

Inkpen, A. C. (1998). Learning and knowledge acquisition through international strategic alliances. The Academy of Management Perspectives, 12(4), 69-80. https://doi.org/10.5465/ame.1998. 1333953.

Inkpen, A. C., \& Tsang, E. W. (2005). Social capital, networks, and knowledge transfer. Academy of Management Review, 30(1), 146165. https://doi.org/10.5465/amr.2005.15281445.

Ismail, K. M. (2012). Theorizing on the role of individualismcollectivism in tacit knowledge transfer between agents in international alliances. International Journal of Knowledge Management, 8(1), 71-85. https://doi.org/10.4018/jkm.2012010104.

Janssen, M., Konopnicki, D., Snowdon, J. L., \& Ojo, A. (2017). Driving public sector innovation using big and open linked data (BOLD). Information Systems Frontiers, 19(2), 189-195. https://doi.org/10. 1007/s10796-017-9746-2.

Jia, L., Song, X., \& Hall, D. (2020). Influence of habits on Mobile payment acceptance: An ecosystem perspective. Information Systems Frontiers, 1-20. https://doi.org/10.1007/s10796-020-10079-4.

Junni, P., \& Sarala, R. M. (2013). The role of absorptive capacity in acquisition knowledge transfer. Thunderbird International Business Review, 55(4), 419-438. https://doi.org/10.1002/tie.21554.

Kang, J., Rhee, M., \& Kang, K. H. (2010). Revisiting knowledge transfer: Effects of knowledge characteristics on organizational effort for knowledge transfer. Expert Systems with Applications, 37(12), 8155-8160. https://doi.org/10.1016/j.eswa.2010.05.072.

Kannisto, P., Hästbacka, D., \& Marttinen, A. (2020). Information exchange architecture for collaborative industrial ecosystem. Information Systems Frontiers, 22(3), 655-670. https://doi.org/10. 1007/s10796-018-9877-0.

Khan, U., \& Haleem, A. (2012). Smart organisations: Modelling of enablers using an integrated ISM and fuzzy-MICMAC approach. 
International Journal of Intelligent Enterprise, 1(3-4), 248-269. https://doi.org/10.1504/ijie.2012.052556.

King, A. W., \& Zeithaml, C. P. (2001). Competencies and firm performance: Examining the causal ambiguity paradox. Strategic Management Journal, 22(1), 75-99. https://doi.org/10.1002/10970266(200101)22:1<75::aid-smj145>3.0.co;2-i.

Ko, D. G., Kirsch, L. J., \& King, W. R. (2005). Antecedents of knowledge transfer from consultants to clients in enterprise system implementations. MIS Quarterly, 59-85. https://doi.org/10.2307/ 25148668.

Koskinen, K. U. (2000). Tacit knowledge as a promoter of project success. European Journal of Purchasing \& Supply Management, 6(1), 41-47. https://doi.org/10.1016/s0969-7012(99)00033-7.

Kovacs, A., Van Looy, B., \& Cassiman, B. (2015). Exploring the scope of open innovation: A bibliometric review of a decade of research. Scientometrics, 104(3), 951-983. https://doi.org/10.1007/s11192015-1628-0.

Kraus, S., Ribeiro-Soriano, D., \& Schüssler, M. (2018). Fuzzy-set qualitative comparative analysis (fsQCA) in entrepreneurship and innovation research-the rise of a method. International Entrepreneurship and Management Journal, 14(1), 15-33. https:// doi.org/10.1007/s11365-017-0461-8.

Kumar, S., Luthra, S., \& Haleem, A. (2013). Customer involvement in greening the supply chain: an interpretive structural modeling methodology. Journal of Industrial Engineering International, 9(1), 113. https://doi.org/10.1186/2251-712X-9-6.

Lane, P. J., Salk, J. E., \& Lyles, M. A. (2001). Absorptive capacity, learning, and performance in international joint ventures. Strategic Management Journal, 22, 1139-1161. https://doi.org/10.1002/smj. 206.

Lauritzen, G. D., \& Karafyllia, M. (2019). Perspective: Leveraging open innovation through paradox. Journal of Product Innovation Management, 36(1), 107-121. https://doi.org/10.1111/jpim.12474.

Lawson, B., \& Potter, A. (2012). Determinants of knowledge transfer in inter-firm new product development projects. International Journal of Operations \& Production Management, 32(10), 1228-1247. https://doi.org/10.1108/01443571211274530.

Lee, J. N. (2001). The impact of knowledge sharing, organisational capability and partnership quality on IS outsourcing success. Information \& Management, 38(5), 323-335. https://doi.org/10. 1016/s0378-7206(00)00074-4.

Lee, C. Y., \& Wu, F. C. (2010). Factors affecting knowledge transfer and absorptive capacity in multinational corporations. The Journal of International Management Studies, 5(2), 118-126. https://doi.org/ 10.1057/jibs.2013.55.

Lee, A. H., Kang, H. Y., \& Chang, C. C. (2011). An integrated interpretive structural modeling-fuzzy analytic network process-benefits, opportunities, costs and risks model for selecting technologies. International Journal of Information Technology \& Decision Making, 10(05), 843-871. https://doi.org/10.1142/ s0219622011004592.

Levin, D. Z., \& Cross, R. (2004). The strength of weak ties you can trust: The mediating role of trust in effective knowledge transfer. Management Science, 50(11), 1477-1490. https://doi.org/10.1287/ mnsc. 1030.0136

Lippman, S. A., \& Rumelt, R. P. (1982). Uncertain imitability: An analysis of interfirm differences in efficiency under competition. The Bell Journal of Economics, 13, 418-438. https://doi.org/10.2307/ 3003464.

Lizardo, O. (2006). How cultural tastes shape personal networks. American Sociological Review, 71(5), 778-807. https://doi.org/10. 1177/000312240607100504.

Majchrzak, A., Markus, M. L., \& Wareham, J. (2016). Designing for digital transformation: Lessons for information systems research from the study of ICT and societal challenges. MIS Quarterly, 40(2), 267-277. https://doi.org/10.25300/misq/2016/40:2.03.
Mandal, A., \& Deshmukh, S. G. (1994). Vendor selection using interpretive structural modelling (ISM). International Journal of Operations \& Production Management, 14(6), 52-59. https://doi.org/10.1108/ 01443579410062086.

Martinkenaite, I. (2011). Antecedents and consequences of interorganizational knowledge transfer: Emerging themes and openings for further research. Baltic Journal of Management, 6(1), 53-70. https://doi.org/10.1108/17465261111100888.

Matzler, K., Friedrich von den Eichen, S., Anschober, M., \& Kohler, T. (2018). The crusade of digital disruption. Journal of Business Strategy, 39(6), 13-20. https://doi.org/10.1108/jbs-12-2017-0187.

Maurer, I., Bartsch, V., \& Ebers, M. (2011). The value of intraorganizational social capital: How it fosters knowledge transfer, innovation performance, and growth. Organization Studies, 32(2), 157-185. https://doi.org/10.1177/0170840610394301.

Mayer, R. C., Davis, J. H., \& Schoorman, F. D. (1995). An integrative model of organizational trust. The Academy of Management Review, 20(3), 709-734. https://doi.org/10.5465/amr.1995.9508080335.

Mazloomi Khamseh, H., \& Jolly, D. R. (2008). Knowledge transfer in alliances: Determinant factors. Journal of Knowledge Management, 12(1), 37-50. https://doi.org/10.1108/13673270810852377.

Michailova, S., \& Mustaffa, Z. (2012). Subsidiary knowledge flows in multinational corporations: Research accomplishments, gaps, and opportunities. Journal of World Business, 47(3), 383-396. https:// doi.org/10.1016/j.jwb.2011.05.006.

Michelfelder, I., \& Kratzer, J. (2013). Why and how combining strong and weak ties within a single interorganizational R\&D collaboration outperforms other collaboration structures. Journal of Product Innovation Management, 30(6), 1159-1177. https://doi.org/10. 1111/jpim. 12052.

Mikalef, P., \& Pateli, A. (2017). Information technology-enabled dynamic capabilities and their indirect effect on competitive performance: Findings from PLS-SEM and fsQCA. Journal of Business Research, 70, 1-16. https://doi.org/10.1016/j.jbusres.2016.09.004.

Mikalef, P., Pappas, I. O., Krogstie, J., \& Pavlou, P. A. (2020a). Big data and business analytics: A research agenda for realizing business value. Information \& Management, 57(1), 103237. https://doi.org/ 10.1016/j.im.2019.103237.

Mikalef, P., Sharma, K., Pappas, I, O., \& Giannakos, M. (2020b). Seeking information on social commerce: An examination of the impact of user-and marketer-generated content through an eyetracking study. Information Systems Frontiers, 1-14. https://doi. org/10.1007/s10796-020-10034-3.

Milagres, R., \& Burcharth, A. (2019). Knowledge transfer in interorganizational partnerships: What do we know? Business Process Management Journal, 25(1), 27-68. https://doi.org/10.1108/bpmj06-2017-0175.

Miller, K., McAdam, R., Moffett, S., Alexander, A., \& Puthusserry, P. (2016). Knowledge transfer in university quadruple helix ecosystems: An absorptive capacity perspective. $R \& D$ Management, 46(2), 383-399. https://doi.org/10.1111/radm.12182.

Minbaeva, D. B., \& Michailova, S. (2004). Knowledge transfer and expatriation in multinational corporations: The role of disseminative capacity. Employee Relations, 26(6), 663-679. https://doi.org/10. 1108/01425450410562236.

Nambisan, S., Wright, M., \& Feldman, M. (2019). The digital transformation of innovation and entrepreneurship: Progress, challenges and key themes. Research Policy, 48(8), 103773. https://doi.org/10. 1016/j.respol.2019.03.018.

Narteh, B. (2008). Knowledge transfer in developed-developing country interfirm collaborations: A conceptual framework. Journal of Knowledge Management, 12(1), 78-91. https://doi.org/10.1108/ 13673270810852403.

Nielsen, B. B. (2005). The role of knowledge embeddedness in the creation of synergies in strategic alliances. Journal of Business 
Research, 58(9), 1194-1204. https://doi.org/10.1016/j.jbusres.2004. 05.001 .

Nishat Faisal, M., Banwet, D. K., \& Shankar, R. (2006). Supply chain risk mitigation: Modelling the enablers. Business Process Management Journal, 12(4), 535-552. https://doi.org/10.1108/ 14637150610678113.

Nonaka, L., Takeuchi, H., \& Umemoto, K. (1996). A theory of organizational knowledge creation. International Journal of Technology Management, 11(7-8), 833-845. https://doi.org/10.1504/IJTM. 1996.025472

Nwankpa, J, K. \& Roumani, Y. (2016). "IT capability and digital transformation: A firm performance perspective." In: Proceedings of the International Conference on Information Systems. https://doi.org/ 10.1016/j.ijinfomgt.2016.05.016, 36, 987, 994.

Ordanini, A., Parasuraman, A., \& Rubera, G. (2014). When the recipe is more important than the ingredients: A qualitative comparative analysis (QCA) of service innovation configurations. Journal of Service Research, 17(2), 134-149. https://doi.org/10.1177/ 1094670513513337.

Ortiz de Guinea, A., \& Raymond, L. (2020). Enabling innovation in the face of uncertainty through IT ambidexterity: A fuzzy set qualitative comparative analysis of industrial service SMEs. International Journal of Information Management, 50, 244-260. https://doi.org/ 10.1016/j.ijinfomgt.2019.05.007.

Oyemomi, O., Liu, S., Neaga, I., Chen, H., \& Nakpodia, F. (2019). How cultural impact on knowledge sharing contributes to organizational performance: Using the fsQCA approach. Journal of Business Research, 94, 313-319. https://doi.org/10.1016/j.jbusres.2018.02. 027

Pak, Y, S., \& Park, Y, R. (2004). A framework of knowledge transfer in cross-border joint ventures: An empirical test of the Korean context. MIR: Management International Review, 417-434. https://doi.org/ $10.1108 / 02651331211216961$

Panteli, N., \& Sockalingam, S. (2005). Trust and conflict within virtual inter-organizational alliances: A framework for facilitating knowledge sharing. Decision Support Systems, 39(4), 599-617. https:// doi.org/10.1016/j.dss.2004.03.003.

Pappas, I. O. (2018). User experience in personalized online shopping: A fuzzy-set analysis. European Journal of Marketing, 52(7/8), 16791703. https://doi.org/10.1108/ejm-10-2017-0707.

Pappas, I. O., \& Woodside, A. G. (2021). Fuzzy-set qualitative comparative analysis (fsQCA): Guidelines for research practice in information systems and marketing. International Journal of Information Management, 58, 102310. https://doi.org/10.1016/j.ijinfomgt.2021. 102310.

Pappas, I. O., Kourouthanassis, P. E., Giannakos, M. N., \& Chrissikopoulos, V. (2016). Explaining online shopping behavior with fsQCA: The role of cognitive and affective perceptions. Journal of Business Research, 69(2), 794-803. https://doi.org/10. 1016/j.jbusres.2015.07.010.

Pappas, I., Mikalef, P., Giannakos, M., \& Pavlou, P. (2017). Value cocreation and trust in social commerce: An Fsqca approach. In: Proceedings of the 25th European conference on information systems (ECIS), (pp. 2153-2168).

Pappas, I. O., Mikalef, P., Giannakos, M. N., Krogstie, J., \& Lekakos, G. (2018). Big data and business analytics ecosystems: Paving the way towards digital transformation and sustainable societies. Information Systems and e-Business Management, 16(3), 479-491. https://doi. org/10.1007/s10257-018-0377-z.

Pappas, I. O., Papavlasopoulou, S., Mikalef, P., \& Giannakos, M. N. (2020). Identifying the combinations of motivations and emotions for creating satisfied users in SNSs: An fsQCA approach. International Journal of Information Management, 53, 102128. https://doi.org/10.1016/j.jinfomgt.2020.102128.

Pera, R., Occhiocupo, N., \& Clarke, J. (2016). Motives and resources for value co-creation in a multi-stakeholder ecosystem: A managerial perspective. Journal of Business Research, 69(10), 4033-4041. https://doi.org/10.1016/j.jbusres.2016.03.047.

Pérez-Nordtvedt, L., Kedia, B. L., Datta, D. K., \& Rasheed, A. A. (2008). Effectiveness and efficiency of cross-border knowledge transfer: An empirical examination. Journal of Management Studies, 45(4), 714 744. https://doi.org/10.1111/j.1467-6486.2008.00767.x.

Pfohl, H. C., Gallus, P., \& Thomas, D. (2011). Interpretive structural modeling of supply chain risks. International Journal of Physical Distribution \& Logistics Management, 41(9), 839-859. https://doi. org/10.1108/09600031111175816.

Pirkkalainen, H., Pawlowski, J. M., Bick, M., \& Tannhäuser, A. C. (2018). Engaging in knowledge exchange: The instrumental psychological ownership in open innovation communities. International Journal of Information Management, 38(1), 277287. https://doi.org/10.1016/j.ijinfomgt.2017.09.006.

Radziwon, A., \& Bogers, M. (2019). Open innovation in SMEs: Exploring inter-organizational relationships in an ecosystem. Technological Forecasting and Social Change, 146, 573-587. https://doi.org/10.1016/j.techfore.2018.04.021.

Ragin, C. C. (2006). Set relations in social research: Evaluating their consistency and coverage. Political Analysis, 14(3), 291-310. https://doi.org/10.1093/pan/mpj019.

Ragin, C. C. (2008). Redesigning social inquiry: Fuzzy sets and beyond. University of Chicago Press.

Ragin, C., \& Fiss, P. (2018). Qualitative Comparative Analysis. Southern California QCA workshop, University of California delivered 29-31 march 2018.

Raj, T., Shankar, R., \& Suhaib, M. (2008). An ISM approach for modelling the enablers of flexible manufacturing system: The case for India. International Journal of Production Research, 46(24), 6883-6912. https://doi.org/10.1080/00207540701429926.

Randhawa, K., Josserand, E., Schweitzer, J., \& Logue, D. (2017). Knowledge collaboration between organizations and online communities: The role of open innovation intermediaries. Journal of Knowledge Management, 21(6), 1293-1318. https://doi.org/10. 1108/jkm-09-2016-0423.

Rauter, R., Globocnik, D., Perl-Vorbach, E., \& Baumgartner, R. J. (2018). Open innovation and its effects on economic and sustainability innovation performance. Journal of Innovation \& Knowledge, 4(4), 226-233. https://doi.org/10.1016/j.jik.2018.03. 004.

Ravi, V., \& Shankar, R. (2005). Analysis of interactions among the barriers of reverse logistics. Technological Forecasting and Social Change, 72(8), 1011-1029. https://doi.org/10.1016/j.techfore. 2004.07.002.

Reed, R., \& DeFillippi, R. J. (1990). Causal ambiguity, barriers to imitation, and sustainable competitive advantage. Academy of Management Review, 15(1), 88-102. https://doi.org/10.5465/amr. 1990.4308277

Rejeb-Khachlouf, N., Mezghani, L., \& Quélin, B. (2011). Personal networks and knowledge transfer in inter-organizational networks. Journal of Small Business and Enterprise Development, 18(2), 278-297. https://doi.org/10.1108/14626001111127070.

Retzer, S., Yoong, P., \& Hooper, V. (2012). Inter-organisational knowledge transfer in social networks: A definition of intermediate ties. Information Systems Frontiers, 14(2), 343-361. https://doi.org/10. 1007/s10796-010-9250-4.

Riasanow, T., Jäntgen, L., Hermes, S., Böhm, M., \& Krcmar, H. (2020). Core, intertwined, and ecosystem-specific clusters in platform ecosystems: Analyzing similarities in the digital transformation of the automotive, blockchain, financial, insurance and IIoT industry. Electronic Markets, 1-16. https://doi.org/10.1007/s12525-02000407-6.

Rihoux, B., \& Lobe, B. (2009). The case for qualitative comparative analysis (QCA): Adding leverage for thick cross-case comparison. 
In D. Byrne \& C. Ragin (Eds.), The Sage handbook of case-based methods (pp. 222-242). SAGE.

Ritala, P., \& Almpanopoulou, A. (2017). In defense of 'eco'in innovation ecosystem. Technovation, 60, 39-42. https://doi.org/10.1016/j. technovation.2017.01.004.

Roberts, J. (2000). From know-how to show-how? Questioning the role of information and communication technologies in knowledge transfer. Technology Analysis \& Strategic Management, 12(4), 429-443. https://doi.org/10.1080/713698499.

Robinot, É., Corne, A., Peypoch, N., \& Trespeuch, L. (2021). Environmental actions and consumer participation: Which impacts on brand relationship? The multiple realities of the hospitality sector. International Journal of Hospitality Management, 92, 102713. https://doi.org/10.1016/j.ijhm.2020.102713.

Rohrbeck, R., Hölzle, K., \& Gemünden, H. G. (2009). Opening up for competitive advantage-how deutsche Telekom creates an open innovation ecosystem. R\&D Management, 39(4), 420-430. https:// doi.org/10.1111/j.1467-9310.2009.00568.x.

Sahney, S. (2008). Critical success factors in online retail-an application of quality function deployment and interpretive structural modeling. International Journal of Business and Information, 3(1), 144-163.

Sahney, S., Banwet, D. K., \& Karunes, S. (2006). An integrated framework for quality in education: Application of quality function deployment, interpretive structural modelling and path analysis. Total Quality Management \& Business Excellence, 17(2), 265-285. https://doi.org/10.1080/14783360500450376.

Samantra, C., Datta, S., Mahapatra, S. S., \& Debata, B. R. (2016). Interpretive structural modelling of critical risk factors in software engineering project. Benchmarking: An International Journal, 23(1), 2-24. https://doi.org/10.1108/bij-07-2013-0071.

Santoro, M. D., \& Bierly, P. E. (2006). Facilitators of knowledge transfer in university-industry collaborations: A knowledge-based perspective. IEEE Transactions on Engineering Management, 53(4), 495507. https://doi.org/10.1109/tem.2006.883707.

Schneider, C. Q., \& Wagemann, C. (2012). Set-theoretic methods for the social sciences: A guide to qualitative comparative analysis. Cambridge University Press.

Seate, A. A., Joyce, N., Harwood, J., \& Arroyo, A. (2015). Necessary and sufficient conditions for positive intergroup contact: A fuzzy set qualitative comparative analysis approach to understanding intergroup attitudes. Communication Quarterly, 63(2), 135-155. https://doi.org/10.1080/01463373.2015.1012215.

Secundo, G., Toma, A., Schiuma, G., \& Passiante, G. (2019). Knowledge transfer in open innovation: A classification framework for healthcare ecosystems. Business Process Management Journal, 25(1), 144-163. https://doi.org/10.1108/bpmj-06-2017-0173.

Shaikh, M., \& Levina, N. (2019). Selecting an open innovation community as an alliance partner: Looking for healthy communities and ecosystems. Research Policy, 48(8), 1-16. https://doi.org/10.1016/ j.respol.2019.03.011.

Shamsudin, S., Mohd Radzi, N. I., \& Othman, R. (2016). Causal ambiguity in lean production implementation in Malaysia. Journal of Asia-Pacific Business, 17(3), 249-266. https://doi.org/10.1080/ 10599231.2016.1203719.

Simonin, B. L. (1999). Ambiguity and the process of knowledge transfer in strategic alliances. Strategic Management Journal, 20(7), 595623. https://doi.org/10.1002/(sici)1097-0266(199907)20:7<595:: aid-smj47>3.3.co;2-x.

Simonin, B. L. (2004). An empirical investigation of the process of knowledge transfer in international strategic alliances. Journal of International Business Studies, 35(5), 407-427. https://doi.org/10. 1057/palgrave.jibs.8400091.

Singh, M. D., \& Kant, R. (2008). Knowledge management barriers: An interpretive structural modeling approach. International Journal of Management Science and Engineering Management, 3(2), 141150. https://doi.org/10.1080/17509653.2008.10671042.
Singh, R. K., Shankar, R., Narain, R., \& Agarwal, A. (2003). An interpretive structural modeling of knowledge management in engineering industries. Journal of Advances in Management Research, 1(1), 28-40. https://doi.org/10.1108/97279810380000356.

Singh, R. K., Garg, S. K., Deshmukh, S. G., \& Kumar, M. (2007). Modelling of critical success factors for implementation of AMTs. Journal of Modelling in Management, 2(3), 232-250. https://doi. org/10.1108/17465660710834444.

Sjödin, D. (2019). Knowledge processing and ecosystem co-creation for process innovation: Managing joint knowledge processing in process innovation projects. International Entrepreneurship and Management Journal, 15(1), 135-162. https://doi.org/10.1007/ s11365-018-0550-3.

Soti, A., Kaushal, O. P., \& Shankar, R. (2011). Modelling the barriers of six sigma using interpretive structural modelling. International Journal of Business Excellence, 4(1), 94-110. https://doi.org/10. 1504/ijbex.2011.037251.

Soto Setzke, D., Riasanow, T., Böhm, M. \& Krcmar, H. (2021). Pathways to digital service innovation: The role of digital transformation strategies in established organizations. Information Systems Frontiers, 1-21. https://doi.org/10.1007/s10796-021-10112-0.

Spulber, D. F. (2012). Tacit knowledge with innovative entrepreneurship. International Journal of Industrial Organization, 30(6), 641-653. https://doi.org/10.1016/j.jijindorg.2012.07.004.

Suominen, A., Seppänen, M., \& Dedehayir, O. (2019). A bibliometric review on innovation systems and ecosystems: A research agenda. European Journal of Innovation Management, 22(2), 335-360. https://doi.org/10.1108/ejim-12-2017-0188.

Szulanski, G., Cappetta, R., \& Jensen, R. J. (2004). When and how trustworthiness matters: Knowledge transfer and the moderating effect of causal ambiguity. Organization Science, 15(5), 600-613. https://doi.org/10.1287/orsc.1040.0096.

Talib, F., Rahman, Z., \& Qureshi, M. N. (2011). Analysis of interaction among the barriers to total quality management implementation using interpretive structural modeling approach. Benchmarking: An International Journal, 18(4), 563-587. https://doi.org/10.1108/ 14635771111147641

Tho, N. D., \& Trang, N. T. M. (2015). Can knowledge be transferred from business schools to business organizations through in-service training students? SEM and fsQCA findings. Journal of Business Research, 68(6), 1332-1340. https://doi.org/10.1016/j.jbusres.2014. 12.003 .

Tripathy, S., Sahu, S., \& Ray, P. K. (2013). Interpretive structural modelling for critical success factors of $R \& D$ performance in Indian manufacturing firms. Journal of Modelling in Management, 8(2), 212-240. https://doi.org/10.1108/jm2-11-2011-0061.

Van Wijk, R., Jansen, J. J., \& Lyles, M. A. (2008). Inter-and intra-organizational knowledge transfer: A meta-analytic review and assessment of its antecedents and consequences. Journal of Management Studies, 45(4), 830-853. https://doi.org/10.1111/j.1467-6486.2008. 00771.x.

Vassilakopoulou, P., \& Hustad, E. (2021). Bridging digital divides: A literature review and research agenda for information systems research. Information Systems Frontiers, 1-15. https://doi.org/10. 1007/s10796-020-10096-3.

Venkatesh, V., Brown, S. A., \& Bala, H. (2013). Bridging the qualitativequantitative divide: Guidelines for conducting mixed methods research in information systems. MIS Quarterly, 37(1), 21-54. https:// doi.org/10.25300/misq/2013/37.1.02.

Veri, F. (2019). Explaining foreigners' political rights in the context of direct democracy: A fuzzy-set QCA of Swiss cantonal popular votes. Politics and Governance, 7(2), 410-426. https://doi.org/10. 17645/pag.v7i2.1779.

Veríssimo, J. M. C. (2016). Enablers and restrictors of mobile banking app use: A fuzzy set qualitative comparative analysis (fsQCA). 
Journal of Business Research, 69(11), 5456-5460. https://doi.org/ 10.1016/j.jbusres.2016.04.155.

Vial, G. (2019). Understanding digital transformation: A review and a research agenda. The Journal of Strategic Information Systems, 28(2), 118-144. https://doi.org/10.1016/j.jsis.2019.01.003.

Wang, W. (2016). Exploring the determinants of network effectiveness: The case of neighborhood governance networks in Beijing. Journal of Public Administration Research and Theory, 26(2), 375-388. https://doi.org/10.1093/jopart/muv017.

Warfield, J. N. (1994). A science of generic design: Managing complexity through systems design (2nd ed.). Iowa State University Press.

Williams, C. (2007). Transfer in context: Replication and adaptation in knowledge transfer relationships. Strategic Management Journal, 28(9), 867-889. https://doi.org/10.1002/smj.614.

Wood, G., Dibben, P., \& Meira, J. (2016). Knowledge transfer within strategic partnerships: the case of HRM in the Brazilian motor industry supply chain. The International Journal of Human Resource Management, 27(20), 2398-2414. https://doi.org/10.1080/ 09585192.2016 .1221841$.

Woodside, A. G. (2013). Moving beyond multiple regression analysis to algorithms: Calling for adoption of a paradigm shift from symmetric to asymmetric thinking in data analysis and crafting theory. Journal of Business Research, 66(4), 463-472. https://doi.org/10.1016/j. jbusres.2012.12.021.

Woodside, A. G. (2014). Embrace• perform• model: Complexity theory, contrarian case analysis, and multiple realities. Journal of Business Research, 67(12), 2495-2503. https://doi.org/10.1016/j.jbusres. 2014.07.006.

Wulf, A., \& Butel, L. (2017). Knowledge sharing and collaborative relationships in business ecosystems and networks: A definition and a demarcation. Industrial Management \& Data Systems, 117(7), 1407-1425. https://doi.org/10.1108/imds-09-2016-0408.

Xie, Y., Gao, S., Jiang, X., \& Fey, C. F. (2015). Social ties and indigenous innovation in China's transition economy: The moderating effects of learning intent. Industry and Innovation, 22(2), 79-101. https://doi. org/10.1080/13662716.2015.1033198.

Xie, X., Fang, L., \& Zeng, S. (2016). Collaborative innovation network and knowledge transfer performance: A fsQCA approach. Journal of Business Research, 69(11), 5210-5215. https://doi.org/10.1016/j. jbusres.2016.04.114.

Zahra, S. A., Zheng, C., \& Yu, J. (2018). Learning advantages of newness: A reconceptualization and contingent framework. Journal of International Entrepreneurship, 16(1), 12-37. https://doi.org/10. 1007/s10843-017-0202-7.

Zhang, Q., \& Zhou, K. Z. (2013). Governing interfirm knowledge transfer in the Chinese market: The interplay of formal and informal mechanisms. Industrial Marketing Management, 42(5), 783-791. https://doi.org/10.1016/j.indmarman.2012.12.002.

Publisher's Note Springer Nature remains neutral with regard to jurisdictional claims in published maps and institutional affiliations.

Dr Emily Bacon is a lecturer in the School of Management, Swansea University. Her PhD research focused on the conditions for knowledge transfer success within innovation ecosystems. Emily's main research interests include knowledge transfer, business relationships (particularly within innovation ecosystems), coopetition, and the application of the analytical techniques fuzzy-set Qualitative Comparative Analysis and Interpretive Structural Modelling.

Professor Michael D. Williams is a Professor in the School of Management, Swansea University. With an academic and professional background in computer science, his current research interests focus primarily upon two of the three pillars of data science: domains and analytics, taking the form of the application of a range of analytical tools and techniques to the analysis of data in order to develop greater understanding of the behaviour of consumers, employees, citizens, markets, and organizations.

Professor Gareth Davies is an Associate Professor based in the School of Management, Swansea University. His research interests span a number of areas include life sciences, innovation management, and marketing. 